\title{
Op reis met de vakantiewetgeving: het Handvest biedt nieuw uitzicht
}

\author{
J.R. Vos
}

\section{$1 \quad$ Inleiding}

Op dinsdag 6 november 2018 wees het Hof van Justitie van de Europese Unie (HvJ EU; hierna: het Hof of het Hof van Justitie) een aantal uitspraken over de Europese vakantiewetgeving. Het betrof de volgende zaken: ${ }^{1}$

- de gevoegde zaken Bauer (C-569/16) en Willmeroth (C-570/16); ${ }^{2}$ en

- Max-Planck zur Förderung der Wissenschaften eV (C-684/16; hierna: MaxPlanck). ${ }^{3}$

In deze zaken komen samen drie onderwerpen naar voren. De zaak Max-Planck introduceert een inspanningsplicht voor de werkgever om zijn werknemers vakantie op te laten nemen. De arresten Bauer en Willmeroth herbevestigen (na Bollacke, 12 juni 2014, C-118/13) het recht van de nabestaanden van een overleden werknemer op een vergoeding voor diens niet-opgenomen vakantie. Tot slot kennen Willmeroth en Max-Planck horizontale directe (of rechtstreekse) werking toe aan artikel 31 lid 2 van het Handvest van de grondrechten van de Europese Unie. Horizontale directe werking houdt kort gezegd in dat (in dit geval) Handvest-bepalingen rechtstreeks doorwerken in de rechtsverhoudingen tussen particulieren onderling (zie ook het slot van deze paragraaf). ${ }^{4}$ In deze bijdrage bespreek ik de arresten en hun betekenis voor artikel 7 van Richtlijn 2003/88 en de mogelijkheden om in horizontale relaties rechtstreekse werking aan Handvestbepalingen toe te kennen.

De opzet van dit artikel is als volgt. Paragraaf 2 beschrijft kort het recht op vakantie in Richtlijn 2003/88 en het Handvest, alsmede enkele andere Handvest-bepalingen. De feiten van de zaken komen in paragraaf 3 aan de orde, waarna in de paragrafen 4 en 5 de conclusies van A-G Bot en de arresten van het Hof volgen. Mijn commentaar op de zaak begint in paragraaf 6 , waar ik de implicaties van de arresten voor het recht op vakantie bespreek. Paragraaf 7 bespreekt de doorwerking van het Handvest. Daarbij bestaat bijzondere aandacht voor de vraag welke rechten voor doorwerking in aanmerking komen en de (problematische) verhouding van deze arresten met eerdere jurisprudentie. Paragraaf 8 bespreekt de

1 Naast de genoemde zaken wees het Hof op dezelfde dag ook de zaak Kreuziger (C-619/16), waarin een soortgelijke uitleg van Richtlijn 2003/88 als in Max-Planck centraal staat. Deze zaak laat ik buiten beschouwing.

2 HvJ EU 6 november 2018, gevoegde zaken C-569/16 (Bauer) en C-570/16 (Willmeroth), ECLI:EU:C:2018:871.

3 HvJ EU 6 november 2018, C-684/16, ECLI:EU:C:2018:874 (Max-Planck zur Förderung der Wissenschaften $\mathrm{eV}$ ).

4 Asser/Hartkamp 3-I 2019/12. 
gevolgen van de arresten voor zowel de doorwerking van het Handvest als de Nederlandse vakantiewetgeving, waarna tot slot een conclusie volgt.

Vooraf nog een aantal opmerkingen. Allereerst een aantal aanduidingskwesties. De gevoegde zaken Bauer en Willmeroth duid ik over het algemeen aan als Bauer. Zowel het Hof van Justitie van de Europese Gemeenschap als het Hof van Justitie van de Europese Unie duid ik aan als het Hof. Het Handvest van de grondrechten van de Europese Unie wordt aangehaald als het Handvest. Voor de goede orde moet dit niet verward worden met het Europees Sociaal Handvest (ESH) en/of het Gemeenschapshandvest van de sociale grondrechten van de werknemers, die beide slechts zelden voorkomen in deze bijdrage.

Tot slot schreef ik hiervoor al dat ik spreek van horizontale directe (of rechtstreekse) werking omdat (in dit geval) Handvest-bepalingen rechtstreeks doorwerken in rechtsverhoudingen tussen particulieren onderling. Reeds het gebruik van dit begrip kan aanleiding geven voor uitvoerige debatten over wat nu directe of indirecte werking is en waar de verschillen en nuances zitten. ${ }^{5} \mathrm{Ik}$ ga in deze bijdrage niet zozeer in op wat nu als directe of indirecte werking wordt aangeduid, maar richt mij meer op de daaropvolgende stappen: hoe pakt de toets die het Hof aanlegt concreet uit en wat werkt (niet) materieel door?

\section{Het recht op vakantie in Richtlijn 2003/88 en het Handvest}

\subsection{Richtlijn 2003/88/EG}

Het recht op vakantie is geregeld in artikel 7 Richtlijn 2003/88/EG (betreffende een aantal aspecten van de organisatie van de arbeidstijd). De richtlijn stelt grenzen aan arbeids- en rusttijden. Artikel 7 van die richtlijn ziet op vakantie en luidt:

\section{'Jaarlijkse vakantie}

1 De lidstaten treffen de nodige maatregelen opdat aan alle werknemers jaarlijks een vakantie met behoud van loon van ten minste vier weken wordt toegekend, overeenkomstig de in de nationale wetten en/of gebruiken geldende voorwaarden voor het recht op en de toekenning van een dergelijke vakantie.

2 De minimumperiode van de jaarlijkse vakantie met behoud van loon kan niet door een financiële vergoeding worden vervangen, behalve in geval van beëindiging van het dienstverband.'

In de afgelopen twintig jaar heeft het Hof regelmatig baanbrekende arresten gewezen op het gebied van vakantie. Een aantal daarvan heeft de interpretatie

5 L.G. Verburg, De invloed van het EU-Handvest op het Nederlandse arbeidsrecht, in: J. Gerards, H. de Waele \& K. Zwaan (red.), Vijf jaar bindend EU-Grondrechtenhandvest - Doorwerking, consequenties, perspectieven, Deventer: Wolters Kluwer 2015, p. 193, koos in diens bijdrage een soortgelijke aanpak. Heldere, korte introducties met verwijzingen zijn te vinden in A. Eleveld, Rechtstreekse horizontale werking van grondrechten van de Europese Unie, NtER 2019/3-4, p. 90 en M. de Mol, Het leerstuk van de horizontale directe werking van Unie-grondrechten op de voet gevolgd, AA 2019/5, p. 371-382. 
van de Nederlandse vakantiewetgeving beïnvloed, zoals bijvoorbeeld het arrest FNV/Staat der Nederlanden. ${ }^{6}$ Een ander voorbeeld is het Schultz-Hoff-arrest. ${ }^{7}$ Dat arrest was ook aanleiding voor de wijziging van de Nederlandse vakantiewetgeving per 1 januari $2012 .^{8}$

\subsection{Het Handvest}

Het Handvest werd in 2000 aangenomen door het Europees Parlement, de Europese Commissie en de Raad van de Europese Unie. Aanleiding voor het Handvest was het advies van het Hof om de (destijds) EG niet toe te laten treden tot het Europees Verdrag voor de rechten van de mens (EVRM). ${ }^{9}$ Als reactie hierop kwam het Handvest tot stand. In 2007 werd het in Straatsburg gewijzigd. Sinds het Verdrag van Lissabon in 2009 kent artikel 6 lid 1 van het Verdrag betreffende de Europese Unie (EU-Verdrag) aan het Handvest dezelfde juridische waarde toe als de verdragen (EU-Verdrag en het Verdrag betreffende de werking van de Europese Unie (VWEU)) en is het Handvest primair gemeenschapsrecht. Dat betekent onder meer dat het voorgaat op EU-wetgeving, zoals verordeningen, richtlijnen en besluiten (voorheen beschikkingen), alsook nationaal recht.

Het Handvest bevat een aantal specifiek arbeidsrechtelijke grondrechten (bijvoorbeeld vakverenigingsvrijheid, collectief arbeidsrecht, medezeggenschapsrecht, arbeidsomstandigheden) en voor het arbeidsrecht relevante grondrechten (gelijke behandeling, rechtsbescherming) ${ }^{10}$ Een van die grondrechten staat genoemd in artikel 31 lid 2: het recht op vakantie.

Dat luidt als volgt:

'Iedere werknemer heeft recht op een beperking van de maximumarbeidsduur en op dagelijkse en wekelijkse rusttijden, alsmede op een jaarlijkse vakantie met behoud van loon.'

Volgens artikel 6 lid 1 alinea 3 VWEU is voor de interpretatie van het Handvest eveneens de Toelichting op het Handvest ${ }^{11}$ van belang. Die luidt, voor zover relevant:

6 HvJ EG 6 april 2006, C-124/05, ECLI:EU:C:2006:244 (FNV/Staat der Nederlanden). Zie hierover bijv. M. Koster, Vakantiedagen: opnemen of uitbetalen? Uitwerking in de praktijk, ArbeidsRecht 2006/64.

7 HvJ EU 20 januari 2019, gevoegde zaken C-350/06 (Schultz-Hoff) en C-520/06 (Stringer), ECLI:EU:C:2009:18. Zie hierover bijv. D.F. Berkhout, Het Schultz-Hoff-arrest: nooit te ziek voor vakantie, TAP 2009/3, p. 107-112.

$8 \quad$ Stb. 2011, 318 en 319.

9 Advies 2/94, ECLI:EU:C:1996:140. Dit advies is later herhaald in Advies 2/13, ECLI:EU:C: 2014:2475. Zie hierover uitgebreid C.J. van de Heyning, Advies 2/13 van het Hof van Justitie: flinke stap terug voor toetreding Europese Unie tot Europees Verdrag tot bescherming van de rechten van de mens, NtER 2015/2, p. 55-61.

10 Zie hierover uitgebreid T. van Peijpe, Toepassing van EU-grondrechten in nationaal arbeidsrecht, TRA 2012/76.

11 PbEU 2007/C 303/02. 
'Lid 2 is gebaseerd op Richtlijn 93/104/EG [thans Richtlijn 2003/88; toevoeging $\mathrm{JRV}^{12}$ ] betreffende een aantal aspecten van de organisatie van de arbeidstijd en op artikel 2 van het ESH en punt 8 van het Gemeenschapshandvest van de sociale grondrechten van de werknemers.'

De in de Toelichting genoemde bronnen voegen weinig toe. Artikel 2 ESH verplicht de partijen bij het Handvest een jaarlijks verlof van ten minste vier weken met behoud van loon te waarborgen. De richtlijn bevat het welbekende artikel 7, en het Gemeenschapshandvest kent werknemers een vakantie toe 'waarvan de duur onderling in opwaartse zin moet worden aangepast, overeenkomstig de nationale gebruiken' (punt 8). Reeds in 2001 haalde A-G Tizzano het artikel aan in het BECTU-arrest. Het Hof noemde het Handvest pas voor het eerst in het arrest Williams/British Airways, zonder er overigens iets mee te (hoeven) doen. ${ }^{13}$ Nadien heeft het Hof artikel 31 lid 2 Handvest vaker genoemd, zonder hieraan tot aan de in deze bijdrage besproken arresten veel betekenis te hechten. ${ }^{14}$

Relevant zijn tot slot bepalingen over de werkingssfeer van het Handvest. Zo luidt artikel 51 lid 1 (Toepassingsgebied Handvest) als volgt:

'1. De bepalingen van dit Handvest zijn gericht tot de instellingen, organen en instanties van de Unie met inachtneming van het subsidiariteitsbeginsel, alsmede, uitsluitend wanneer zij het recht van de Unie ten uitvoer brengen, tot de lidstaten. Derhalve eerbiedigen zij de rechten, leven zij de beginselen na en bevorderen zij de toepassing ervan overeenkomstig hun respectieve bevoegdheden en met inachtneming van de grenzen van de bevoegdheden zoals deze in de Verdragen aan de Unie zijn toegedeeld.'

Artikel 52 handelt over de reikwijdte en uitlegging van de rechten en beginselen van het Handvest. De voor deze zaak relevante artikelleden zijn de volgende:

'1. Beperkingen op de uitoefening van de in dit Handvest erkende rechten en vrijheden moeten bij wet worden gesteld en de wezenlijke inhoud van die rechten en vrijheden eerbiedigen. Met inachtneming van het evenredigheidsbeginsel kunnen slechts beperkingen worden gesteld, indien zij noodzakelijk zijn en daadwerkelijk beantwoorden aan door de Unie erkende doelstellingen van algemeen belang of aan de eisen van de bescherming van de rechten en vrijheden van anderen.

(...)

12 Het Hof omschrijft Richtlijn 2003/88 als (her)codificatie van Richtlijn 93/104 en overweegt daarom dat deze eveneens in aanmerking moet worden genomen bij de interpretatie van het Handvest, zie bijv. Bauer, nr. 56. Dat lijkt mij juist.

13 Arrest Williams/British Airways, reeds aangehaald.

14 Zie voor een uitvoerig overzicht van artikel 31 Handvest: A. Bogg, Article 31, in: S. Peers e.a. (red.), The EU Charter of Fundamental Rights: A Commentary, Oxford/Portland: Hart Publishing 2014, p. 833-868. De ontwikkeling van artikel 31 lid 2 Handvest in de jurisprudentie van het Hof is te vinden op p. $845-848$. 
5. Aan de bepalingen van dit Handvest die beginselen bevatten, kan uitvoering worden gegeven door wetgevings- en uitvoeringshandelingen van de instellingen, organen en instanties van de Unie en door handelingen van de lidstaten wanneer zij het recht van de Unie ten uitvoer brengen, bij de uitoefening van hun respectieve bevoegdheden. De rechterlijke bevoegdheid ten aanzien van die bepalingen blijft beperkt tot de uitlegging van genoemde handelingen en de toetsing van de wettigheid ervan.'

Het Handvest maakt dus onderscheid tussen rechten en beginselen. Waar rechten moeten worden geëerbiedigd, geven beginselen geen aanleiding tot directe eisen tot het nemen van positieve maatregelen door EU-instellingen of -lidstaten. Beginselen zijn dus minder snel inroepbaar dan rechten. Weliswaar kunnen zij nog steeds worden getoetst, maar die toetsing is blijkens artikel 52 lid 5 Handvest beperkt. Onduidelijk is echter wanneer nu sprake is van een recht of van een beginsel. Daardoor is het evenmin duidelijk welke artikelen nu rechten, beginselen of een combinatie van beide behelzen. De Toelichting geeft slechts enkele voorbeelden van beginselen en van artikelen die een combinatie van rechten en beginselen behelzen. Helaas zijn niet alle artikelen ingedeeld. ${ }^{15}$

\section{Feiten}

\subsection{Bauer en Willmeroth}

Bauer is weduwe en enig rechtsopvolger van haar echtgenoot, die in 2010 is overleden en bij leven in dienst was bij Stadt Wuppertal. Stadt Wuppertal heeft Bauers verzoek om uitbetaling van door haar echtgenoot niet-opgenomen 25 vakantiedagen (ter waarde van $€ 5857,75$ ) afgewezen. Broßonn is enig rechtsopvolger van haar in 2013 overleden echtgenoot. Ook zijn voormalig werkgever, Willmeroth, weigert de niet-opgenomen (32) vakantiedagen - ter waarde van $€ 3702,72$ - uit te betalen. Bauer en Broßonn starten afzonderlijk procedures bij het Arbeitsgericht, die uiteindelijk bij het Bundesarbeitsgericht belanden, ${ }^{16}$ de hoogste federale rechter in arbeidszaken in Duitsland.

Het Bundesarbeitsgericht stelt prejudiciële vragen. Het wijst erop dat het Hof in het arrest Bollacke ${ }^{17}$ oordeelde dat artikel 7 Richtlijn 2003/88 aldus moet worden uitgelegd dat het in de weg staat aan nationale wetten of gebruiken volgens welke het recht op jaarlijkse vakantie met behoud van loon vervalt zonder dat een recht ontstaat op een financiële vergoeding voor niet-opgenomen vakantie in geval van beëindiging van het dienstverband door het overlijden van de werknemer. Het Bundesarbeitsgericht vraagt zich echter af of dit ook geldt wanneer in het nationale recht is bepaald dat een dergelijke financiële vergoeding geen deel kan uitmaFundamental Rights: A Commentary, Oxford/Portland: Hart Publishing 2014, p. 1413-1454. 
ken van de nalatenschap, zoals uit $\S 7(4)$ van het Bundesurlaubsgesetz (de Duitse federale vakantiewet) zou volgen. Elke andere uitlegging zou volgens het Bundesarbeitsgericht een uitleg contra legem zijn en dus niet kunnen worden aanvaard. Voorts wijst het Bundesarbeidsgericht op het arrest KHS, ${ }^{18}$ waarin het Hof heeft gewezen op het doel van vakantie: recuperatie en ontspanning. Dit doel is in geval van overlijden niet te realiseren. Het Bundesarbeitsgericht vraagt zich daarom af of het recht op vakantie of een vervangende vergoeding dan ook niet moet vervallen in geval van overlijden. Een andersluidende beslissing suggereert immers dat het recht op vakantie met behoud van loon tevens tot bescherming van de erfgenamen van de overleden werknemer strekt.

Tot slot merkt het Bundesarbeitsgericht op dat de zaak Willmeroth twee particulieren betreft. Het vraagt zich af of in een dergelijke context sprake kan zijn van de eventuele rechtstreekse werking van artikel 7 Richtlijn 2003/88 en/of artikel 31 lid 2 Handvest. Het stelt dan ook de volgende twee vragen (de tweede alleen in Willmeroth): ${ }^{19}$

'1. Verleent artikel 7 van richtlijn [2003/88/EG] of artikel 31, lid 2, van het [Handvest] de erfgenaam van een tijdens zijn dienstverband overleden werknemer een aanspraak op financiële vergoeding voor de minimale jaarlijkse vakantie waarop de werknemer recht had vóór zijn overlijden, hetgeen volgens $\S 7$, lid 4, [BUrlG] juncto $\S 1922$, lid 1, [BGB] is uitgesloten?

2. Bij een bevestigend antwoord op de eerste vraag: geldt dit ook in geval van een dienstverband tussen twee particulieren?'

\subsection{Max-Planck}

Tetsuji Shimizu is van 1 augustus 2001 tot en met 31 december 2013 in dienst van Max-Planck. Als duidelijk is dat de arbeidsovereenkomst van Shimizu eindigt, verzoekt Max-Planck hem op 23 oktober 2013 zijn nog resterende vakantiedagen op te nemen vóór het einde van het dienstverband. Shimizu neemt slechts twee dagen op. Daags voordat zijn arbeidsovereenkomst eindigt, verzoekt hij uitbetaling van de resterende niet-opgenomen 51 vakantiedagen. Max-Planck weigert en daarop start Shimizu een procedure.

Als de procedure daar eenmaal is aanbeland, overweegt het Bundesarbeitsgericht dat het Bundesurlaubgesetz onduidelijk is ten opzichte van Richtlijn 2003/88, het Handvest en de rechtspraak van het Hof. § 7(3) van het Bundesurlaubgesetz bepaalt namelijk dat vakantieaanspraken in het lopende jaar moeten worden opgenomen. Overdracht naar een volgend jaar is slechts mogelijk als dringende bedrijfsbelangen of met de werknemer verband houdende redenen dit rechtvaardigen. Weliswaar beschrijft $\S 7(4)$ dat niet-opgenomen vakantie aan het einde van het dienstverband wordt uitbetaald, maar dat is slechts mogelijk als diens - tijdige - vakantieaanvraag is geweigerd. Tegelijkertijd kan een werknemer niet worden verplicht vakantie op te nemen. Het Bundesarbeitsgericht vraagt zich af 
of het artikel in overeenstemming met de richtlijn is, en of deze regels ook direct tussen particulieren hebben te gelden.

Het Bundesarbeitsgericht stelt dan ook de volgende vragen: ${ }^{20}$

'1. Staat artikel 7 van richtlijn [2003/88] of artikel 31, lid 2, van het [Handvest] in de weg aan een nationale regeling als die van $\S 7$ [BUrlG], volgens welke een werknemer die zijn recht op jaarlijkse vakantie wil uitoefenen daadwerkelijk vakantie moet aanvragen met opgave van de periode waarin hij deze wil opnemen, dit teneinde te vermijden dat zijn recht op vakantie aan het einde van het referentietijdvak zonder mogelijkheid tot vergoeding komt te vervallen, en volgens welke de werkgever niet verplicht is om zelf eenzijdig en op voor de werknemer bindende wijze het tijdstip van de vakantie binnen het referentietijdvak vast te leggen?

2. Ingeval de eerste vraag bevestigend wordt beantwoord: Geldt dit evenzeer wanneer het gaat om een dienstverband tussen particulieren?'

\section{Conclusies A-G Bot}

De conclusies van A-G Bot lijken op elkaar. In de conclusie bij de zaak Max-Planck verwijst hij voor wat betreft de doorwerking zelfs rechtstreeks naar de conclusie bij de zaak Bauer. Ik bespreek de conclusies onderwerpsgewijs.

\subsection{Vergoeding bij overlijden (Bauer)}

De vraag over Richtlijn 2003/88 kost A-G Bot weinig moeite en hij herhaalt hier hetgeen het Hof in Bollacke overwoog, namelijk dat artikel 7 impliceert dat bij overlijden een recht ontstaat op een vergoeding voor niet-opgenomen vakantie. De twee 'nieuwe' argumenten (dus: het doel van vakantie en de erfrechtkwestie) van het Bundesarbeitsgericht doet hij snel af. Hij overweegt allereerst dat het doel van vakantie geen afbreuk kan doen aan de door het Hof in Bollacke gekozen interpretatie. Conform dit arrest overweegt A-G Bot dat het nuttig effect van de richtlijn verloren gaat als bij overlijden geen vergoeding voor niet-genoten vakantiedagen wordt toegekend. ${ }^{21}$ Het recht zou dan met terugwerkende kracht verloren gaan door een 'toevallige omstandigheid', waarover werknemer noch werkgever controle heeft. ${ }^{22}$ Ook met het erfrechtargument maakt de A-G korte metten. Volgens de A-G zijn deze vragen niet nieuw, maar zijn zij met het wijzen van het arrest Bollacke reeds beantwoord. Zij speelden toen namelijk al en zijn dus niet ontstaan door het wijzen van dat arrest. Dat volgt volgens de A-G uit door het Bundesarbeitsgericht aangehaalde rechtspraak. ${ }^{23}$ Bij gebreke van (echt) nieuwe argumenten pleit de A-G dus voor het bevestigen van Bollacke, namelijk dat artikel 7 Richtlijn 2003/88 in de weg staat aan een nationale regeling die nabe-

20 Arrest Max-Planck, nr. 17. Vindplaats uitspraak verwijzende rechter: Bundesarbeitsgericht 13 december 2016, ECLI:DE:BAG:2016:131216.B.9AZR541.15A.0 (9 AZR 541/15).

21 Conclusie A-G Bot in Bauer, ECLI:EU:C:2018:337, nrs. 24-25.

22 Conclusie A-G Bot in Bauer, nr. 27.

23 Conclusie A-G Bot in Bauer, nrs. 28-31. 
staanden bij het overlijden van de werknemer uitsluit van het recht op de vergoeding voor niet-genoten vakantiedagen. ${ }^{24}$

\subsection{Inspanningsplicht (Max-Planck)}

In het arrest Max-Planck komt vooral de vraag over de interpretatie van artikel 7 Richtlijn 2003/88 aan de orde. Volgens A-G Bot gaat het er met name om of de werknemer daadwerkelijk de mogelijkheid heeft gehad vakantie op te nemen. ${ }^{25}$ Vakantie biedt immers rust en ontspanning. De werkgever heeft daarom een bijzondere verantwoordelijkheid ervoor te zorgen dat werknemers daadwerkelijk vakantie opnemen. ${ }^{26}$ Het moet worden verhinderd dat de werkgever de werknemer - als zwakkere partij binnen het dienstverband - kan beperken in zijn rechten. ${ }^{27}$ De A-G suggereert hier dus dat de werkgever een actieve, positieve verplichting heeft: hij moet er zo veel mogelijk voor zorgen dat de werknemer vakantie opneemt.

Volgens de A-G rust daarbij op de werkgever een informatieplicht: hij moet tijdig precieze informatie verstrekken, zodat werknemers weten dat hun vakantieaanspraken kunnen vervallen zonder dat zij recht hebben op een vergoeding. Dit moet zich eveneens vertalen in een bewijsregeling. Vakantieaanspraken kunnen pas vervallen als is nagegaan of de werknemer daadwerkelijk vakantie heeft kunnen nemen. Anders zou het recht op vakantie worden uitgehold. ${ }^{28}$

A-G Bot bespreekt ook de vergoeding bij einde van het dienstverband conform artikel 7 lid 2 Richtlijn 2003/88. Hoewel dit recht niet restrictief mag worden uitgelegd en slechts twee voorwaarden stelt (namelijk dat (1) een arbeidsovereenkomst moet zijn geëindigd en (2) niet alle vakantiedagen zijn opgenomen), ${ }^{29}$ is het wél de bedoeling dat de vakantie wordt opgenomen. ${ }^{30}$ Het niet-opnemen van vakantie om bij einde van het dienstverband een vergoeding te krijgen zou immers een met de richtlijn onverenigbare prikkel vormen om afstand te doen van vakantierust. Volgens de A-G moet daarom de vergoeding voor niet-genoten vakantie kunnen vervallen als de werknemer geen vakantie heeft opgenomen terwijl hij hiertoe wel in staat was. ${ }^{31}$ De rechter moet nagaan of de werkgever geschikte maatregelen heeft genomen. ${ }^{32}$ De A-G concludeert dat de richtlijn zich verzet tegen een regeling als de Duitse. 


\subsection{Directe werking artikel 31 Handvest}

In Bauer beantwoordt A-G Bot wat heeft te gelden nu het Bundesurlaubgesetz strijdig is met Richtlijn 2003/88. In Max-Planck verwijst dezelfde A-G naar zijn conclusie in eerstgenoemde zaak. ${ }^{33}$

Aan het begin van zijn conclusie in Bauer stelt A-G Bot vast dat het niet rechtstreeks werken van richtlijnen de concrete werking van sociale grondrechten kan ondermijnen. Hij neemt als uitgangpunt dat de in het Handvest erkende grondrechten waar mogelijk moeten worden beschermd. ${ }^{34}$

De A-G zet de mogelijkheden van richtlijnconforme interpretatie uiteen, inclusief het verbod op interpretatie contra legem en de verplichting zo nodig vaste rechtspraak te wijzigen. ${ }^{35}$ Dat laatste lijkt de A-G in dit geval niet onmogelijk. ${ }^{36} \mathrm{Als}$ dit niettemin tóch onmogelijk zou blijken, is het de vraag of Bauer en Broßonn artikel 7 lid 2 Richtlijn 2003/88 rechtstreeks tegenover hun werkgever kunnen inroepen. Bauer kan dit, nu Stadt Wuppertal een publiekrechtelijk orgaan is, daarmee onderdeel van een EU-lidstaat en dus geen voordeel mag trekken uit incorrecte implementatie van de richtlijn. Artikel 7 lid 1 van de richtlijn was blijkens het arrest Dominguez ${ }^{37}$ in een dergelijk geval al rechtstreeks in te roepen nu dit recht 'nauwkeurig en onvoorwaardelijk' omschreven was; volgens de A-G geldt voor het tweede lid hetzelfde. ${ }^{38}$

Voor Broßonn ligt het moeilijker. Willmeroth is namelijk een privaatrechtelijke rechtspersoon zonder staatsinmenging. Volgens A-G Bot is de oplossing in dit geval 'bochtiger en niet zonder hindernissen'. ${ }^{39} \mathrm{Nu}$ het Bundesurlaubgesetz de tenuitvoerlegging van Richtlijn 93/104 (voorloper van Richtlijn 2003/88) en daarmee EU-recht vormt, kan artikel 31 lid 2 Handvest worden toegepast. ${ }^{40}$ Artikel 31 lid 2 Handvest is gebaseerd op verschillende bronnen (zie paragraaf 2), waaronder Richtlijn 93/104. Die richtlijn is vervolgens vervangen door Richtlijn 2003/88. Uit de formulering van artikel 7 blijkt dat hiervan niet kan worden afgeweken en dat alle werknemers dus jaarlijks een vakantie met behoud van loon van ten minste vier weken toekomt. ${ }^{41}$ Volgens het Hof moet dit recht worden beschouwd als een bijzonder belangrijk beginsel van sociaal recht van de Unie, waaraan de bevoegde nationale autoriteiten slechts uitvoering mogen geven binnen de uitdrukkelijk in Richtlijn 2003/88 zelf bepaalde grenzen. ${ }^{42}$

Volgens de A-G is het tijd voor een stap naar de kwalificatie als volwaardig sociaal grondrecht, waarvoor versterking van de afdwingbaarheid nodig is. ${ }^{43}$ Vervolgens

Conclusie A-G Bot in Max-Planck, nr. 64.

Conclusie A-G Bot in Bauer, nrs. 3-8.

Onder verwijzing naar HvJ EU 19 april 2016, C-441/14, ECLI:EU:C:2016:278 (Rasmussen), nr. 33 en aldaar aangehaalde rechtspraak en HvJ EU 17 april 2018, C-414/16, ECLI:EU:C:2018:257 (Egenberger), nr. 72.

Conclusie A-G Bot in Bauer, nrs. 36-42.

HvJ EU 24 januari 2012, C-282/10, ECLI:EU:C:2012:33 (Dominguez).

Conclusie A-G Bot in Bauer, nrs. 44-50.

Conclusie A-G Bot in Bauer, nr. 51.

Conclusie A-G Bot in Bauer, nr. 52.

Conclusie A-G Bot in Bauer, nr. 55.

Conclusie A-G Bot in Bauer, nrs. 54-55.

Conclusie A-G Bot in Bauer, nr. 57. 
behandelt de A-G de door het Hof in het arrest Association de médiation sociale (AMS) gehanteerde methode. ${ }^{44} \mathrm{Als}$ oplossing heeft het Hof in dat arrest de mogelijkheid geopend met de richtlijn strijdige bepalingen buiten toepassing te laten, naar analogie met het arrest Kücükdeveci. ${ }^{45}$ Dat is mogelijk wanneer het betrokken artikel van het Handvest op zichzelf volstaat om particulieren een recht te verlenen waarop deze zich kunnen beroepen. De bepaling moet dan vanwege haar intrinsieke eigenschappen, zoals deze uit de bewoordingen ervan blijken, dwingend van aard zijn en op zich volstaan. ${ }^{46}$ Anders dan in AMS is in deze zaak met artikel 31 lid 2 Handvest wél sprake van een artikel dat op zichzelf aan particulieren een inroepbaar recht toekent, dat geen nadere uitwerking in Unie- en nationaalrechtelijke voorschriften nodig heeft. ${ }^{47}$

A-G Bot gaat ook in op artikel 51 Handvest. Daarin staat weliswaar dat het Handvest is gericht aan de EU-instellingen en de -lidstaten voor zover zij EU-recht uitvoeren, maar dit sluit inroepbaarheid door burgers volgens de A-G niet uit. Bovendien overweegt de A-G dat het Hof al eerder horizontale werking heeft toegekend aan primaire EU-rechtsbepalingen die volgens hun bewoordingen aan lidstaten waren gericht. ${ }^{48}$ De A-G concludeert dan ook tot handhaving van de rechtsregel uit Bollacke en daarbij ook tot het op grond van het Handvest buiten toepassing laten van de daarmee strijdige Duitse bepalingen.

\section{Hof van Justitie}

De arresten kennen een vergelijkbare opzet. Eerst bespreekt het Hof de prejudiciele vraag over artikel 7 van de richtlijn. ${ }^{49}$ Vervolgens bespreekt het de vraag bezien vanuit artikel 31 lid 2 Handvest. Tot slot komt de doorwerking aan bod.

\subsection{Vergoeding bij overlijden (Bauer)}

Het Hof herhaalt in wezen Bollacke. Artikel 7 van de richtlijn kent twee aspecten: het recht op vakantie én het recht op loon tijdens die vakantie. Artikel 7 lid 2 Richtlijn 2003/88 stelt twee voorwaarden: het dienstverband moet zijn beëindigd en de werknemer moet niet reeds alle vakantie hebben opgenomen. ${ }^{50}$ De reden van beëindiging van het dienstverband doet er niet toe. Anders dan A-G Bot gaat het Hof nadrukkelijk(er) in op de argumenten van de verwijzende rechter. Het klopt dat de overleden werknemer inderdaad niet de mogelijkheid heeft vakantie te gebruiken voor rust en ontspanning. Evenwel kan niet worden aanvaard dat een dergelijke omstandigheid leidt tot het totale verlies van het verworven recht, dat een tweede even belangrijk aspect omvat: het recht op vergoeding. ${ }^{51}$ Verder

44 HvJ EU 15 januari 2014, C-176/12, ECLI:EU:C:2014:2 (Association de médiation sociale).

45 HvJ EU 19 januari 2010, C-555/07, ECLI:EU:C:2010:21 (Kücükdeveci).

46 Conclusie A-G Bot in Bauer, nr. 80.

47 Conclusie A-G Bot in Bauer, nrs. 71-76 en 79-84.

48 Conclusie A-G Bot in Bauer, nrs. 77-78.

49 Volledigheidshalve verklaarde het Hof de prejudiciële vragen in Bauer eerst ontvankelijk. Zie nrs. 20-29.

50 Arrest Bauer, nr. 44.

51 Arrest Bauer, nr. 46. 
merkt het Hof op dat het recht op vakantie met behoud van loon vanuit financieel oogpunt louter vermogensrechtelijk van aard is, en als zodanig bestemd is om aan het vermogen te worden toegevoegd. Het overlijden van de werknemer kan er niet toe leiden dat dit vermogen met terugwerkende kracht aan de nalatenschap wordt onttrokken, waardoor de erfgenamen de aanspraak verliezen. Het verlies van het recht op vakantie of de vervangende vergoeding bij beëindiging van het dienstverband, zonder dat de werknemer daadwerkelijk de mogelijkheid heeft gehad dat recht uit te oefenen, zou immers het wezen zelf van dat recht uithollen. ${ }^{52}$ Een financiële vergoeding bij beëindiging van het dienstverband door het overlijden van de werknemer acht het Hof dus noodzakelijk om het nuttig effect van het recht op vakantie met behoud van loon te waarborgen. ${ }^{53}$

Vervolgens beantwoordt het Hof de vraag van het Bundesarbeitsgericht vanuit het Handvest, nu de daarin opgenomen grondrechten toepassing kunnen hebben in alle situaties die beheerst worden door het recht van de Unie. ${ }^{54}$ Uit de bewoordingen van artikel 31 lid 2 Handvest blijkt dat in die bepaling het 'recht' op jaarlijkse vakantie met behoud van loon is neergelegd. ${ }^{55}$ Het Hof noemt vervolgens de in de Toelichting opgesomde bronnen en wijst erop dat het al eerder heeft gepreciseerd dat de woorden 'jaarlijkse vakantie met behoud van loon' in artikel 7 lid 1 Richtlijn 2003/88 gelijk staan aan 'periode van vakantie met behoud van loon' in artikel 31 lid 2 Handvest. ${ }^{56}$ Ook uit het Handvest volgt daarom dat het recht op vakantie twee aspecten heeft (vakantie en loon). Dat recht kan slechts worden beperkt als aan de voorwaarden van artikel 52 lid 1 Handvest wordt voldaan en de wezenlijke inhoud van het recht wordt geëerbiedigd. Lidstaten kunnen niet-genoten opgebouwde jaarlijkse vakantie aan het einde van een referentie- en/of overdrachtsperiode niet laten vervallen indien de werknemer zijn vakantie niet heeft kunnen opnemen. ${ }^{57}$ Dit geldt ook voor het verlies met terugwerkende kracht van het recht op vakantie of een compenserende vergoeding als gevolg van overlijden. Niet alleen uit Richtlijn 2003/88, maar ook uit artikel 31 lid 2 Handvest volgt dus dat de nabestaanden aanspraak hebben op de vergoeding voor niet-genoten vakantie. $^{58}$

\subsection{Inspanningsplicht (Max-Planck)}

Het Hof herformuleert de eerste vraag (geparafraseerd) als volgt: staan artikel 7 van de richtlijn en artikel 31 lid 2 Handvest in de weg aan een nationale regeling op grond waarvan een werknemer die er niet om heeft verzocht zijn vakantie in de referentieperiode op te nemen, deze rechten aan het einde van die periode ver-

57 Arrest Bauer, nr. 59.

58 Arrest Bauer, nr. 61. 
liest, net als het recht op vergoeding van de niet-opgenomen vakantie bij het einde van het dienstverband?

Het Hof stelt vast dat de zaak draait om een weigering tot betaling van een vergoeding voor niet-genoten vakantiedagen bij einde dienstverband ex artikel 7 lid 2 van de richtlijn. Dit lid beoogt een werknemer te compenseren voor vakantie die hij niet heeft kunnen opnemen (onder verwijzing naar Bollacke). ${ }^{59}$ Het stelt slechts twee voorwaarden: (1) dat de arbeidsovereenkomst is geëindigd, en (2) dat nog vakantieaanspraken resteren. ${ }^{60}$ Het Hof wijst op eerdere rechtspraak over situaties waarin vakantieaanspraken niet vervallen, namelijk bij ziekte (SchultzHoff) en overlijden (Bollacke). ${ }^{61}$ In wezen komen die arresten erop neer dat het recht op vakantie zou worden uitgehold als het recht op vakantie verloren gaat, zonder dat de werknemer de mogelijkheid heeft gehad vakantie op te nemen. ${ }^{62}$

Vervolgens overweegt het Hof dat het voornaamste punt in deze zaak is of er nog rechten zijn die voor vergoeding in aanmerking komen (op grond van artikel 7 lid 1 van de richtlijn). De vraag is volgens het Hof dan ook of behoud van het recht op vakantie afhankelijk kan zijn van een verzoek van de werknemer, zonder welk verzoek het recht op vakantie komt te vervallen. Dit terwijl de werknemer zelf niet verplicht is de vakantie eenzijdig en voor de werknemer bindend vast te stellen. ${ }^{63}$

Hoewel het niet zo is dat vakantie niet verloren kán gaan, mag de richtlijn niet restrictief worden uitgelegd ten koste van werknemers die hieraan rechten ontlenen. Artikel 7 lid 1 van de richtlijn beoogt dat werknemers hun vakantie daadwerkelijk opnemen, en lid 2 draagt daaraan bij door afkoop slechts bij het einde van de arbeidsovereenkomst toe te staan. ${ }^{64}$ Lidstaten kunnen blijkens artikel 7 lid 1 van de richtlijn in hun nationale recht wel voorwaarden voor uitvoering en uitoefening van het recht op vakantie vastleggen. $\S 7$ van het Bundesurlaubgesetz is zo'n regeling die ernaar streeft rekening te houden met de verschillende betrokken belangen. Er moet echter op worden toegezien dat het recht op vakantie niet vervalt zonder dat de werknemer de mogelijkheid heeft gehad deze op te nemen. ${ }^{65}$

Op dezelfde wijze als de A-G komt het Hof vervolgens tot het oordeel dat de zwakke positie van de werknemer moet worden beschermd om het opnemen van vakantie te waarborgen. Een inspanningsplicht voor de werkgever is daarvoor de beste oplossing, zodat de werknemer daadwerkelijk de mogelijkheid heeft vakantie op te nemen. De werkgever moet bewijzen dat hij aan deze plicht heeft voldaan. ${ }^{66}$ Het Hof sluit - evenals de A- $\mathrm{G}^{67}$ - af met de opmerking dat elke uitlegging 
van artikel 7 die de werknemer ertoe kan aanzetten weloverwogen af te zien van het nemen van vakantie, strijdig is met het doel van het recht. ${ }^{68}$

$\mathrm{Na}$ de behandeling van artikel 7 van de richtlijn gaat het Hof ook nu in op artikel 31 lid 2 Handvest. De in paragraaf 5.1 genoemde bronnen van het Handvest leiden voor de inspanningsplicht tot de conclusie dat lidstaten daarom niet kunnen afwijken van het beginsel dat vakantieaanspraken niet kunnen vervallen indien de werknemer deze niet heeft kunnen opnemen. ${ }^{69}$ Zodoende kan het recht niet vervallen indien niet is nagegaan of de werknemer van het recht gebruik heeft kunnen maken. Dat kan pas als de werknemer welbewust en met volledige kennis van de gevolgen alsnog geen vakantie heeft opgenomen. Ook hier krijgt artikel 31 lid 2 Handvest dus dezelfde inhoud als artikel 7 van de richtlijn. ${ }^{70}$

\subsection{Directe werking artikel 31 Handvest}

De volgende vraag is of een met de richtlijn en artikel 31 lid 2 Handvest strijdige regeling buiten toepassing moet worden gelaten in een geding tussen particulieren. $\mathrm{Nu}$ Bauer in dienst was van een publiekrechtelijk orgaan, moeten met de richtlijn strijdige bepalingen in zijn geval buiten toepassing worden gelaten. ${ }^{71}$ Een beroep op het Handvest is hier dus niet noodzakelijk. Broßonn en Willmeroth (en Shimizu en Max-Planck) zijn echter beiden particulieren, waardoor de richtlijn niet rechtstreeks tussen hen kan gelden, zelfs wanneer die bepaling duidelijk, nauwkeurig omschreven en onvoorwaardelijk is. ${ }^{72}$ Daarom is het de vraag of het Handvest dat wel kan.

Volgens het Hof is het recht op jaarlijkse vakantie met behoud van loon een wezenlijk beginsel van sociaal recht van de Unie. ${ }^{73}$ Het verwijst andermaal naar de hiervoor genoemde rechtsbronnen van artikel 31 lid 2 Handvest, en voegt hieraan ILO-Verdrag nr. 132 toe, dat we al kennen uit het arrest Schultz-Hoff en overweging 6 van Richtlijn 2003/88. ${ }^{74}$ Het recht op vakantie is dus niet ingevoerd door de Richtlijnen 93/104 en 2003/88, maar door verschillende internationale instrumenten en heeft als wezenlijk beginsel van sociaal recht een dwingend karakter. Dat wezenlijke beginsel omvat het recht op vakantie als zodanig en het recht op vergoeding. ${ }^{75}$

Door in dwingende bewoordingen te bepalen dat 'iedere werknemer' het 'recht' heeft op 'jaarlijkse vakantie met behoud van loon' zonder te verwijzen naar 'de gevallen (...) en de voorwaarden waarin het recht van de Unie en nationale wetgevingen en praktijken voorzien', geeft artikel 31 lid 2 Handvest uitdrukking aan dit wezenlijke beginsel, waarvan afwijking slechts onder strikte voorwaarden mogelijk is. Het recht op een periode van jaarlijkse vakantie met behoud van loon is 
zowel dwingend als onvoorwaardelijk van aard en hoeft niet nader te worden geconcretiseerd door bepalingen van het recht van de Unie of van nationaal recht. Die bepalingen moeten louter de juiste duur van de jaarlijkse vakantie en in voorkomend geval bepaalde voorwaarden voor de uitoefening van het recht aangeven. ${ }^{76}$ De bepaling volstaat daarom op zichzelf om werknemers een recht te verlenen dat zij jegens hun werkgever kunnen uitoefenen op een gebied dat onder het Unierecht en daarmee binnen het Handvest valt. ${ }^{77}$

Als de situaties binnen de werkingssfeer vallen, heeft artikel 31 lid 2 Handvest tot gevolg dat de nationale rechter een strijdige nationale regeling die het recht op (kort gezegd) een uitkering voor niet-genoten vakantie bij overlijden uitsluit dan wel verval van vakantie (en vergoeding van niet-genoten vakantie aan het einde van het dienstverband) toestaat zonder dat een werkgever aan zijn inspanningsplicht heeft voldaan, buiten toepassing moet laten. Tegelijk impliceert het artikel dat werkgevers zich niet op een dergelijke nationale regeling kunnen beroepen om zich te onttrekken aan hun verplichtingen. ${ }^{78}$

Hoewel de bepalingen van het Handvest blijkens artikel 51 lid 1 zijn gericht tot instellingen, organen en instituties van de Unie, met inachtneming van het subsidiariteitsbeginsel, alsook tot lidstaten voor zover zij recht van de Unie ten uitvoer brengen, regelt het niets over particulieren. Het artikel sluit dus evenmin uit dat zij zich op het Handvest kunnen beroepen. ${ }^{79}$ Het Hof concludeert dan ook dat de met artikel 31 lid 2 Handvest strijdige bepalingen buiten toepassing moeten worden gelaten in gedingen tussen particulieren.

\section{Commentaar: het recht op vakantie}

\subsection{Vergoeding bij overlijden (Bauer)}

Zoals reeds beschreven vormt het arrest Bauer wat betreft artikel 7 lid 1 Richtlijn 2003/88 eigenlijk een herhaling van de zaak Bollacke. De toch bepaald niet onterechte vragen van het Bundesarbeitsgericht serveert het Hof af vanwege de 'tweeaspectenleer' (het recht op vakantie én vergoeding daarop). Ook zou het recht op vakantie met terugwerkende kracht worden uitgehold als na overlijden geen vergoeding voor niet-genoten vakantiedagen wordt uitgekeerd.

Op deze redenering valt wel wat af te dingen. Waarom wordt het recht op vakantie uitgehold als dit in een bijzonder geval als overlijden verloren gaat? Het is immers bedoeld voor de werknemer zelf. ${ }^{80}$ Daarbij is de 'twee-aspectenleer' van het Hof niet onaantastbaar. In Max-Planck (en overigens ook al in Schultz-Hoff) zien we nu juist dat ook het recht op vergoeding kán vervallen, mits de werknemer maar in staat is geweest (of beter: is gesteld) daadwerkelijk vakantie op te nemen. Tot slot is het vreemd dat de door het Bundesarbeitsgericht terecht

76 Arrest Bauer, nrs. 84-85 en Max-Planck nr. 75.

77 Arrest Bauer, nr. 85.

78 Arrest Bauer, nr. 86.

79 Arrest Bauer, nrs. 87-88 en Max-Planck, nr. 76.

80 Zie in gelijke zin B. Vitez, Holiday Pay: Now also to Be Enjoyed during the Afterlife, European Law Reporter 2014, 4, p. 114-118. 
aangestipte, zo belangrijk geachte recuperatiefunctie van vakantie - basis voor menig Hof-arrest en reden dat zoveel nationale bepalingen in strijd zijn gebleken met de richtlijn - nu wel heel makkelijk wordt weggeschreven.

Te gemakkelijk doet het Hof de erfrechtkwestie af als 'al beoordeeld' (in Bollacke). Anders dan A-G Bot en het Hof doen voorkomen, is deze vraag niet inhoudelijk - en zeker niet nadrukkelijk - beoordeeld. De redenering in Bollacke eindigt namelijk met de overweging dat het recht op vakantie (of vervangende vergoeding) niet met terugwerkende kracht kan worden ontnomen. Het Hof maakt daarin echter niet duidelijk waarom dat zo is. De verwijzing van het Hof naar het arrest Maschek, dat op zijn beurt weer gebaseerd is op het arrest Neidel, is geen rechtvaardiging. ${ }^{81}$ In Maschek ging het weliswaar eveneens om een vergoeding op grond van artikel 7 lid 2, maar in dat geval eindigde de arbeidsovereenkomst wegens pensionering. Ook dat arrest - bovendien zonder conclusie gewezen besteedt evenwel geen aandacht aan de vraag waarom een werknemer na afloop van het dienstverband aanspraak kan maken op een recht - of de financiële vervanging ervan - dat niet meer als recuperatie kan gelden.

Bij overlijden speelt bovendien nog iets anders. Omdat na overlijden geen sprake meer van is een arbeidsovereenkomst, is het de vraag of de EU, en daarmee het Hof, wel bevoegd is uitkeringen voor niet-genoten vakantiedagen bij overlijden voor te schrijven. Bij mijn weten heeft de EU namelijk geen bevoegdheid waar het gaat om nationaal (materieel) erfrecht, maar enkel over formele aspecten van het internationaal erfrecht, zoals bijvoorbeeld de vaststelling van het toepasselijke (erf)recht. ${ }^{82}$ Dat gezegd hebbende erkent artikel 17 Handvest nog wel het recht op eigendom, dat blijkens de Toelichting erop overeenstemt met artikel 1 van het Protocol bij het EVRM. ${ }^{83}$ Dat artikel wordt zo geïnterpreteerd dat het ook vorderingen en contractuele rechtsposities omvat. ${ }^{84}$ Ook een opengevallen nalatenschap valt onder het recht op eigendom. ${ }^{85}$ Tegelijk laat artikel 1 van het Protocol de ruimte aan staten om de gebruikmaking van eigendom te reguleren. Dat is bijvoorbeeld mogelijk in het algemeen belang. Het is lastig te beoordelen of artikel 1 lidstaten in dit geval voldoende ruimte biedt om vererving van een vergoeding voor niet-genoten vakantiedagen niet toe te staan. $\mathrm{Nu}$ de Duitse verwijzende rechter aangeeft dat het nationale erfrecht zich verzet tegen de vererving van de vergoeding van vakantie, had het Hof dat wellicht toch moeten beoordelen. Het

81 HvJ EU 20 juli 2016, C-341/15, ECLI:EU:C:2016:576 (Maschek); HvJ EU 3 mei 2012, C-337/10, ECLI:EU:C:2012:263 (Neidel).

82 Verordening (EU) nr. 650/2012 van het Europees Parlement en de Raad betreffende de bevoegdheid, het toepasselijke recht, de erkenning en de tenuitvoerlegging van beslissingen en de aanvaarding en de tenuitvoerlegging van authentieke akten op het gebied van erfopvolging, alsmede betreffende de instelling van een Europese erfrechtverklaring, PbEU 2012, L 201/107. Zie uitgebreid: J.G. Knot, De Europese Erfrechtverordening: nieuwste loot aan de stam van het Europese IPR, NtER 2012/8/9, p. 278-287. Dat de bevoegdheid van de EU beperkt is tot het 'IPR-erfrecht' neemt uiteraard niet weg dat lidstaten eigen regels kunnen stellen over hoe om te gaan met de vergoeding voor niet-genoten vakantie na het overlijden van de werknemer. Zie hiervoor in het bijzonder de noot van E. Kohne bij het arrest Bollacke in JIN 2014/144. 
Hof passeert deze argumenten volledig en daarmee gaat het te kort door de bocht. $\mathrm{Al}$ met al hadden de bepaald niet zinloze argumenten van de Duitse rechter een beter lot verdiend, maar het Hof handhaaft met een doelredenering helaas enkel de bestaande rechtspraak. ${ }^{86}$

\subsection{Inspanningsplicht (Max-Planck)}

Het Hof beschouwt het Bundesurlaubgesetz als uitvoeringsmodaliteit zoals beschreven in artikel 7 lid 1 Richtlijn 2003/88, die ernaar streeft 'rekening te houden met de verschillende betrokken belangen'. ${ }^{87}$ Zo'n uitvoeringsmodaliteit moet wel worden getoetst: er moet op worden toegezien dat het recht op vakantie niet vervalt zonder dat de werknemer de mogelijkheid heeft gehad deze op te nemen. ${ }^{88}$

Een kritieke plaats in de toetsing van die uitvoeringsmodaliteit wordt toebedeeld aan de ongelijkheidscompensatie. De ongelijke verhouding tussen werkgever en werknemer zou ertoe kunnen leiden dat de werknemer - als zwakkere partij in de arbeidsrelatie - zijn vakantie niet durft op te nemen uit angst voor represailles. ${ }^{89}$ Die angst is niet ongegrond. Ook in de Nederlandse jurisprudentie zijn voorbeelden bekend van zaken waarin (al dan niet terecht) is overgegaan tot ontslag op staande voet vanwege het tegen de wil van de werkgever in opnemen van vakantie. ${ }^{90}$ Weliswaar mogen werknemers zich gesteund weten door het arrest Conley King, ${ }^{91}$ waaruit volgt dat een werkgever het een werknemer niet mag beletten vakantie op te nemen en deze vervolgens te laten vervallen, maar het Hof wil kennelijk een stap verder. Ook verwijst het Hof naar het arrest FNV/Staat der Nederlanden, ${ }^{92}$ waarin het prikkels om afstand te doen van de vakantierust verbood. Daaraan voegt het Hof in het arrest Max-Planck een extra element toe: de verantwoordelijkheid voor het opnemen van vakantie mag niet enkel bij de werknemer liggen. Anderzijds hoeft de werkgever de werknemer ook niet te verplichten vakantie op te nemen. Het Hof introduceert dus een inspanningsverplichting, geen resultaatsverplichting. Het betreft een positieve (actieve) verplichting: de werkgever moet iets doen.

De inspanningsplicht kenmerkt zich door een aantal elementen. Ten eerste moet de werkgever er concreet en in alle transparantie voor zorgen dat de werknemer

86 Inmiddels heeft het Bundesarbeitsgericht de zaak na terugverwijzing beslecht in lijn met het arrest Bauer. Zie Bundesarbeitsgericht 22 januari 2019, ECLI:DE:BAG:2019:220119.U. 9AZR45.16.0 (Bauer). De uitkomst van de zaken Broßonn/Wilmeroth en Max-Planck is mij overigens niet bekend.

87 Arrest Max-Planck, nrs. 36-37, onder verwijzing naar HvJ EU 10 september 2009, C-277/08, ECLI:EU:C:2009:542 (Vicente Pereda), nr. 22.

88 Arrest Max-Planck, nr. 38.

89 Overigens is de ongelijkheidscompensatie niet onbekend in de Arbeidstijdenrichtlijn. Het Hof introduceerde dit al in het arrest Fuß (25 november 2010, C-429/09, ECLI:EU:C:2010:717), waar het ging om het claimen van een schadevergoeding wegens de overschrijding van de maximaal toegestane arbeidstijd.

90 HR 14 maart 2008, JAR 2008/109; Hof Den Bosch 20 mei 2014, JAR 2014/161. Zie recenter ook Ktr. Leeuwarden 18 januari 2017, ECLI:NL:RBNNE:2017:185.

91 HvJ EU 29 november 2018, ECLI:EU:C:2017:914, C-214/16 (Conley King).

92 Arrest FNV/Staat der Nederlanden, reeds aangehaald. 
daadwerkelijk de mogelijkheid heeft om zijn jaarlijkse vakantie op te nemen, en hem er zo nodig formeel toe aanzetten dat te doen. De A-G koppelt deze inspanningsplicht in zijn conclusie mede aan artikel 5 lid 1 Richtlijn 89/391, dat bepaalt dat de werkgever verplicht is te zorgen voor de veiligheid en gezondheid van werknemers inzake alle met het werk verbonden aspecten, ${ }^{93}$ al behandelt hij deze inspanningsplicht niet diepgaander dan het Hof. Duidelijk is wel dat op de werkgever een informatieplicht rust. Het informeren van de werkgever moet 'op precieze wijze en tijdig zodat die vakantie de betrokkene nog de rust en ontspanning kan bieden waaraan zij wordt geacht bij te dragen'. ${ }^{94}$ Eveneens moet de werknemer erop worden gewezen dat de niet-opgenomen vakantieaanspraken verloren kunnen gaan. De vraag is wat 'tijdig' in deze context betekent. Allereerst lijkt het erop dat een werknemer nog de tijd moet hebben zijn vakantie te organiseren. Die verplichting volgt in Nederland uit artikel 7:638 lid 4 van het Burgerlijk Wetboek (BW). Ook de A-G hintte hier in zijn conclusie op: nu Max Planck Shimizu pas op 23 oktober 2013 verzocht vakantie op te nemen, terwijl de arbeidsovereenkomst 31 december 2013 zou eindigen, achtte hij het verzoek tardief. ${ }^{95}$ Niet duidelijk is of het grote aantal openstaande dagen (51) hierin nog een rol heeft gespeeld, al zou dat niet verbazen.

Tegelijkertijd koppelt het Hof de tijdige aansporing nadrukkelijk aan de recuperatiefunctie. Concreet kan dit betekenen dat de werkgever moet inschatten wanneer een werknemer de vakantie moet hebben opgenomen voordat de recuperatiefunctie verloren gaat. Dat lijkt vergezocht, maar het past volledig in de recuperatiefunctie die het Hof zo belangrijk vindt en in de verwijzing van de A-G naar Richtlijn 89/391.

Wat 'precies' informeren betekent, wordt niet geheel duidelijk. Dit lijkt te zien op zowel de omvang van het vakantiesaldo als de datum waarop deze aanspraken vervallen. Met 'concreet en in alle transparantie' lijkt te worden bedoeld dat een werkgever de werknemer persoonlijk moet aanspreken. Het rondsturen van een automatisch gegenereerd vakantiesaldo-overzicht en een algemene aansporing van de hr-afdeling om maar vakantie op te nemen, lijkt in die optiek onvoldoende. ${ }^{96}$

A-G Bot suggereert overigens ook dat zelfs een tijdig verzoek van de werkgever tot het opnemen van vakantie niet altijd zal betekenen dat niet-opgenomen vakantie vervalt. Hij overweegt namelijk dat een werknemer in de periode voorafgaand aan het einde van een arbeidsovereenkomst voor bepaalde tijd niet in staat is daadwerkelijk zijn recht op jaarlijkse vakantie met behoud van loon te genieten. Volgens hem zal de werknemer gezien 'de huidige toestand op de arbeidsmarkt' in die periode meer bezig zijn met het zoeken van een nieuwe baan dan met uitrusten en ontspannen. Bovendien kan de werknemer terecht het verlangen hebben projecten naar behoren af te ronden, hetgeen aanleiding kan zijn af te zien van 
het opnemen van vakantie. ${ }^{97}$ Die stellingnames lijken mij te algemeen om hier veel waarde aan te hechten. Met het werkloosheidspercentage en het percentage onvervulde vacatures ging het (vanuit werknemersperspectief) op het moment van het nemen van de conclusie (mei 2018) niet per se slecht. ${ }^{98}$ Daarnaast hangt het er natuurlijk van af of de werknemer al een nieuwe baan heeft en of hij degene is die per se de projecten moet afronden. Wél is de overweging een vingerwijzing om de beoordeling of een werknemer in staat is geweest vakantie op te nemen vooral te bezien op basis van de voorliggende feiten.

Tot slot legt het Hof in overweging 46 de bewijslast nadrukkelijk bij de werkgever. Dat verwondert niet, gelet op de verantwoordelijkheid die toch al op hem rust. Slechts indien het bewijs is geleverd, kan een werkgever zich op het verval van het vakantiesaldo beroepen zonder de richtlijn te schenden. Ook het recht op de vergoeding op grond van lid 2 gaat dan verloren. Vanzelfsprekend wordt het bewijs schriftelijk geleverd. ${ }^{99}$

\subsection{Het recht op vakantie volgens het Handvest}

In zowel de zaak Bauer als de zaak Max-Planck besteedt het Hof aandacht aan de inhoud van het recht op vakantie volgens het Handvest. Dat is nodig, omdat die inhoud noodzakelijk is voor eventuele rechtstreekse werking. De uitvoerige overwegingen komen erop neer dat het Hof de inhoud van artikel 31 lid 2 Handvest rechtstreeks lijkt in te vullen met de inhoud van artikel 7 Richtlijn 2003/88, inclusief bijbehorende jurisprudentie. Het Hof benadrukt vooral de bronnen van het Handvest-artikel. ${ }^{100}$ Eveneens wijst het erop dat beperkingen slechts zijn toegelaten volgens de voorwaarden van artikel 52 lid 1 Handvest en wanneer de wezenlijke inhoud van het recht wordt geëerbiedigd. Het recht op vakantie in het Handvest wordt dus stevig neergezet.

Overigens valt op dat het Hof het recht op vakantie in de context van het Handvest als wezenlijk beginsel van sociaal recht van de Unie aanduidt. ${ }^{101}$ Dat lijkt een promotie: eerder werd het nagenoeg altijd als 'bijzonder belangrijk beginsel van gemeenschapsrecht' aangeduid. De gevolgen van deze nieuwe duiding zijn niet duidelijk. Slechts eerder in Bollacke werd het recht op vakantie eveneens als wezenlijk beginsel aangeduid, maar in dat arrest ontbrak dan weer elke verwijzing naar het Handvest. ${ }^{102}$ Wellicht maakt het verschil in terminologie niet zoveel uit. Een ander opmerkelijk feit is dat het Hof het recht op vakantie een wezenlijk beginsel blijft noemen. Dit terwijl A-G Bot in zijn conclusie een expliciete uitnodiging deed om het niet meer als (bijzonder belangrijk) beginsel aan te duiden, maar toch vooral als een 'volwaardig sociaal grondrecht'. ${ }^{103}$ Tegelijkertijd kan men zeg-

97 Conclusie A-G Bot in Max-Planck, nr. 61.

98 https://ec.europa.eu/eurostat/statistics-explained/index.php?title=Job_vacancy_statistics; https://ec.europa.eu/eurostat/statistics-explained/index.php/Unemployment_statistics\#Longerterm_unemployment_trends.

99 Zie in gelijke zin Funke in zijn noot bij Max-Planck, JAR 2018/318.

100 Arrest Bauer, nr. 55.

101 Arrest Bauer, nrs. 58 en 80.

102 Arrest Bollacke, nr. 20.

103 Conclusie A-G Bot in Bauer, nr. 57. 
gen dat dit verschil in aanduiding niet veel uitmaakt, nu het Hof het recht op vakantie later toch echt als recht behandelt. ${ }^{104}$ Niettemin is het inconsequente gebruik van terminologie wel opvallend.

\section{Horizontale directe werking van het Handvest}

\subsection{Aanleiding: doorwerking van richtlijnen}

Lidstaten moeten richtlijnen omzetten in hun nationale wetgeving. Als dat niet (goed) gebeurt, ontstaan problemen. Particulieren kunnen een richtlijn immers niet rechtstreeks tegen elkaar inroepen. ${ }^{105}$ In zo'n situatie is er een aantal manieren waarop burgers alsnog (enige) bescherming aan de richtlijn kunnen ontlenen. De eerste methode is richtlijnconforme interpretatie. Rechters moeten het nationale recht zo veel mogelijk in overeenstemming met de richtlijn uitleggen. De werkgever moet alle middelen gebruiken die tot zijn beschikking staan. ${ }^{106} \mathrm{Zo}$ nodig moet vaste rechtspraak worden gewijzigd. ${ }^{107}$ Richtlijnconforme interpretatie mag echter niet leiden tot een uitleg contra legem, een uitleg tegen de wettekst in.

Een tweede vorm van rechtsbescherming is staatsaansprakelijkheid. Het Hof heeft deze leer, bekend geworden als de Francovich-doctrine, in een aantal arresten uitgewerkt. ${ }^{108}$ Nederland kent een in vergelijking met Francovich soepeler aansprakelijkheidsregime. De staat is er namelijk voor verantwoordelijk dat het nationale recht in overeenstemming is met hoger recht. Is dat niet het geval, dan is de staat in beginsel aansprakelijk voor onrechtmatige wetgeving. De staat kan zo nodig wel feiten en omstandigheden stellen die meebrengen dat hij niet aansprakelijk is. ${ }^{109}$

Beide methoden kennen hun beperkingen. Staatsaansprakelijkheid is een lastige weg. Het kan immers moeilijk zijn vast te stellen wat de geleden schade is. Ook richtlijnconforme interpretatie kent haar beperkingen, zoals het genoemde verbod op een interpretatie contra legem.

Het derde 'correctief' is het buiten toepassing laten van met Europees recht strijdige bepalingen. Dit is een gedeeltelijke oplossing voor de hiervoor genoemde problemen. Die weg is het Hof voor het eerst ingeslagen in het Mangold-arrest. ${ }^{110}$

104 Arrest Bauer, nrs. 84-85.

105 HvJ EG 14 juli 1994, C-91/92, ECLI:EU:C:1994:292 (Faccini Dori). Laatstelijk werd dit herbevestigd in het arrest Smith, reeds aangehaald.

106 Het is niet altijd duidelijk hoe ver de rechter hierin kan/moet gaan. In het Albron-arrest (HR 5 april 2013, ECLI:NL:HR:2013:BZ1780) ging de rechter ver. Zie bijv. J.H. Even, Richtlijnconform: that's the answer, Annotaties AR Updates 2013-0276; P.C. Vas Nunes, Tegen de wet, ArA 2016/3, p. 64-65; F.G. Laagland, De zaak Rasmussen: de verregaande invloed van Europese richtlijnen op het Nederlandse arbeidsrecht en de transitievergoeding in het bijzonder, AR Updates 2016-0445.

107 HvJ EU 19 april 2016, C-441/14 (Rasmussen).

108 Zie hierover uitgebreid mijn noot bij Hof Den Haag 15 oktober 2013, JIN 2014/2.

109 Zie (mijn noot bij) HR 18 september 2015, JAR 2015/257, in het bijzonder r.o. 3.5.2. In andere landen geldt de Francovich-norm nog wel. Zie bijv. C. K. Klasen, Liability for not reacting in time to ECJ decision regarding holiday pay (DK), EELC 2018/10.

110 HvJ EG 22 november 2005, C-144/04 (Mangold). 
In dat arrest oordeelde het Hof onder meer dat de nationale rechter, om de volle werking van het algemene beginsel van non-discriminatie op grond van leeftijd te verzekeren, elke strijdige bepaling van nationaal recht buiten toepassing moet laten, zelfs terwijl de omzettingsperiode voor Richtlijn 2000/78 nog niet was verstreken. Deze lijn werd vervolgens in Kücükdeveci bevestigd. ${ }^{111}$ Het Hof herhaalde dat Richtlijn 2000/78 het beginsel van gelijke behandeling in arbeid en beroep slechts concretiseert, zonder dat dit in de richtlijn verankerd is, en bovendien dat het beginsel van non-discriminatie op grond van leeftijd een algemeen beginsel van Unierecht is.

In Kücukdeveci verwees het Hof voor het eerst ook naar artikel 21 Handvest. ${ }^{112}$ Dat leidde tot de vraag waar het buiten toepassing laten van met een richtlijn strijdige bepalingen nu op was gebaseerd. Gold het enkel voor het beginsel van non-discriminatie of ook voor andere Handvest-bepalingen? ${ }^{113}$ En was voor doorwerking nu een richtlijn nodig of niet?

\subsection{Welke rechten werken door?}

Om tot horizontale directe werking van het Handvest te komen moet een aantal vragen worden beantwoord: ${ }^{114}$

- Valt de situatie onder het Unierecht?

- Is het recht geschikt voor doorwerking?

- Geldt het Handvest in particuliere rechtsverhoudingen?

In deze paragraaf komen vooral de twee laatste vragen aan de orde. De eerste vraag kan in deze zaken namelijk kort worden beantwoord. Het Handvest is blijkens artikel 51 lid 1 alleen van toepassing op (kortweg) EU-instellingen, -organen, -instanties en -lidstaten, en die laatste uitsluitend wanneer zij het recht van de Unie ten uitvoer brengen. Bij toetsing van nationale wetgeving aan het Handvest zal dus eerst moeten worden stilgestaan bij de vraag of er wel recht van de Unie wordt uitgevoerd, maar dat is al snel het geval omdat uit het arrest Åkerberg/Fransson blijkt dat het Handvest ook ziet op nationale regelingen die binnen de werkingssfeer van het Europees recht vallen. ${ }^{115}$ Ook de arresten Bauer en Max-Planck voldoen aan deze eis, nu het Bundesurlaubgesetz Richtlijn 2003/88 uitvoert. ${ }^{116}$

\subsection{Is het recht geschikt voor doorwerking?}

Zoals in paragraaf 2 is beschreven, schrijft artikel 51 lid 1 Handvest voor dat rechten worden geëerbiedigd en dat beginselen worden nageleefd. Artikel 52 lid 5

111 Reeds aangehaald.

112 Arrest Kücükdeveci, nr. 22. Zie uitgebreid Vas Nunes 2016, p. 54-80.

113 M. de Mol, Dominguez: A Deafening Silence, European Constitutional Law Review 2012, 8, p. 280-303.

114 Zie hierover uitgebreid De Mol 2019.

115 HvJ EU 26 februari 2013, C-617/10, ECLI:EU:C:2013:105 (Åkerberg Fransson). Zie hierover uitgebreid: M.A. Fierstra, Åkerberg Fransson: ruim toepassingsgebied van Handvest op handelingen van lidstaten, NtER 2013, 6, p. 197-205. Een uitzondering is overigens HvJ EU 10 mei 2011, C-147/08, ECLI:EU:C:2011:286 (Römer).

116 Arrest Bauer, nr. 53 en arrest Max-Planck, nr. 50. 
Handvest bepaalt dat de rechterlijke bevoegdheid ten aanzien van beginselen beperkt is tot uitlegging van handelingen van lidstaten of EU-instanties en toetsing van de wettigheid ervan. Op het eerste gezicht lijkt het dus belangrijk of een Handvest-artikel een recht of een beginsel behelst.

Het Hof koos in de zaak AMS echter voor een ander onderscheid dan rechten en beginselen. In die zaak stond de Franse implementatiewetgeving van de Informatie- en consultatierichtlijn (Richtlijn 2002/14) ter discussie. In de Franse wetgeving waren ten onrechte bepaalde categorieën werknemers uitgesloten in de toepassing van getalscriteria, zoals wij in Nederland bijvoorbeeld kortwerkende uitzendkrachten niet hoeven mee te tellen. Op grond van de wet meende AMS, de werkgever in deze zaak, dat de vakbonden geen recht hadden een personeelsvertegenwoordiger aan te stellen waar dat anders wel het geval zou zijn geweest. Daarop volgde een procedure, die er uiteindelijk toe leidde dat het Hof de Franse implementatiewetgeving in strijd met de richtlijn achtte. Nu de richtlijn geen directe horizontale werking had, kwam aan de orde of artikel 27 Handvest dat wel had. Artikel 27 Handvest kent werknemers(vertegenwoordigers) namelijk een recht toe op tijdige informatie en raadpleging, zulks in de gevallen en onder de voorwaarden waarin het recht van de Unie en de nationale wetgevingen en praktijken voorzien. De vraag was dus of de Franse rechter met artikel 27 Handvest strijdige wetgeving buiten toepassing moest laten, zulks vergelijkbaar met het arrest Kücükdeveci.

A-G Cruz-Villalón paste in zijn conclusie bij het arrest het hiervoor weergegeven systeem van rechten en beginselen toe. Hij concludeerde dat artikel 27 Handvest een beginsel behelst waaraan de Franse wetgeving langs de band van artikel 52 lid 5 Handvest kon worden getoetst. ${ }^{117}$ Volgens de A-G werd artikel 27 Handvest namelijk 'wezenlijk en rechtstreeks' geconcretiseerd door artikel 3 lid 1 Richtlijn 2002/14. ${ }^{118} \mathrm{Nu}$ de wetgeving met die richtlijn strijdig was, concludeerde de A-G tot het buiten toepassing laten van de Franse wetgeving.

Het Hof koos echter voor een andere benadering. Het overwoog dat de grondrechten van de Unie toepassing kunnen vinden in alle situaties die het recht van de Unie beheerst. ${ }^{119}$ Uit artikel 27 Handvest volgt evenwel dat het artikel pas zijn volle werking krijgt nadat het nader is uitgewerkt in Unierechtelijke en nationaalrechtelijke voorschriften. ${ }^{120}$ Omdat het getalscriterium niet uit het Handvest (of de Toelichting) volgt, kon het artikel niet direct horizontaal doorwerken. Daarmee verschilde volgens het Hof de zaak AMS van het arrest Kücükdeveci, omdat het beginsel van non-discriminatie op grond van leeftijd in die zaak op zichzelf volstond. Het Hof achtte het onmogelijk dit gebrek van artikel 27 Handvest te repareren door het te lezen in samenhang met Richtlijn 2002/14. Het Handvestartikel op zichzelf moet namelijk volstaan. ${ }^{121}$ Het Hof concludeerde dus dat de

117 Conclusie A-G Cruz-Villalón in AMS, ECLI:EU:C:2013:491, nrs. 43-80.

118 Conclusie A-G Cruz-Villalón in AMS, nr. 80.

119 Arrest AMS, nrs. 42-43.

120 Arrest AMS, nr. 45.

121 Arrest AMS, nr. 49. 
litigieuze Franse bepaling niet buiten toepassing kon worden gelaten: slechts de Francovich-doctrine kon in dit geval oplossing bieden. ${ }^{122}$

Het Hof beoordeelde dus niet of er sprake was van een recht of een beginsel. ${ }^{123}$ In plaats daarvan vroeg het zich af of de bepaling in kwestie op zichzelf volstond om er rechten aan te ontlenen: is het dwingend en onvoorwaardelijk van aard, zonder dat een nadere concretisering nodig is? Terecht heeft De Mol dan ook geconcludeerd dat hieruit volgt dat alle Uniegrondrechten a priori in aanmerking zouden komen voor horizontale directe werking - mits het recht in kwestie ertoe strekt. $^{124}$

In het arrest Egenberger kende het Hof vervolgens voor het eerst daadwerkelijk horizontale directe werking toe aan Handvest-bepalingen, namelijk artikel 21 (non-discriminatieverbod) en artikel 47 (effectieve rechtsbescherming). ${ }^{125}$ Egenberger vormt daarmee in zoverre een verschuiving ten opzichte van Mangold en Kücükdeveci dat de horizontale directe werking rechtstreeks aan het Handvest werd ontleend in plaats van aan het algemeen beginsel van Unierecht in combinatie met de richtlijn. ${ }^{126}$ Hoewel het recht aan het Handvest werd ontleend, betrof Egenberger wederom een discriminatiezaak. Op dat terrein was de doorwerkingsdoctrine al bekend. Het bleef dus onduidelijk of men zich ook direct op het Handvest kon beroepen in een zaak buiten dit terrein.

\subsection{Bauer en Max-Planck: problematische verhouding met AMS}

In Bauer en Max-Planck wordt voor het eerst horizontale rechtstreekse werking toegekend in een zaak die niet aan discriminatie gerelateerd is. Het Hof borduurt voort op het arrest AMS en overweegt dat het recht op jaarlijkse vakantie met behoud van loon volgens artikel 31 lid 2 Handvest zowel dwingend als onvoorwaardelijk van aard is en niet nader hoeft te worden geconcretiseerd met bepalin-

122 Arrest AMS, nr. 50.

123 Zie in gelijke zin F. Dorssemont, The Right to Information and Consultation in Article 27 of the Charter of Fundamental Rights of the European Union: Less than a Right and Less than a Principle, just an Ordinary Provision Lacking Direct Effect?, Maastricht Journal of European and Comparative Law 2014, p. 719. Anderen maken het onderscheid tussen rechten en beginselen nog wel. Zie bijv. Verburg 2015, p. 170-171 en 176-179 en H.C.F.J.A. de Waele, Horizontale werking van het EU-Grondrechtenhandvest: de kogel lijkt door de kerk, NtER 2014, 5, p. 158-164. A-G Bot lijkt in zijn conclusie in Bauer (nrs. 68-70) te suggereren dat men ook kan betogen dat het Hof in AMS het verschil tussen rechten en beginselen nog steeds heeft geëerbiedigd, maar dat in die visie rechten dan volledig en rechtstreeks in rechte geldend kunnen worden gemaakt. Ik begrijp de redeneringen van Verburg, De Waele en A-G Bot zo, dat rechten de 'AMS-toets' doorstaan (en daardoor dus 'recht' zijn), maar beginselen niet. De praktische gevolgen van deze kwalificatieverschillen lijken mij echter nihil.

124 Annotatie M. de Mol bij AMS in EHRC 2014/70. Overigens heeft Dorssemont (2014) AMS bekritiseerd (met name op p. 721-722). Hij stelt - mijns inziens terecht - dat het door het Hof geïntroduceerde criterium ertoe leidt dat bescherming van het Handvest verloren gaat. Door de introductie van de eis dat een Handvest-bepaling geen nadere uitwerking nodig heeft, kan het Hof niet direct optreden tegen een situatie die evident onwetmatig is.

125 Arrest Egenberger, reeds aangehaald.

126 Zie hierover uitgebreid E. Frantziou, Mangold Recast? The ECJ's Flirtation with Drittwirkung in Egenberger, https://europeanlawblog.eu/2018/04/24/mangold-recast-the-ecjs-flirtation-withdrittwirkung-in-egenberger, 24 april 2018. 
gen van het recht van de Unie of van nationaal recht, 'welke bepalingen louter de juiste duur van de jaarlijkse vakantie en in voorkomend geval bepaalde voorwaarden voor de uitoefening van dat recht dienen aan te geven'. ${ }^{127}$

Het Hof zet de voortaan te varen koers dus overtuigend neer. Kritisch beschouwd is deze echter niet zonder problemen. Artikel 31 lid 2 Handvest is volgens het Hof dwingend en onvoorwaardelijk. ${ }^{128}$ Maar is dat wel zo? Ten eerste is de duur van vakantie niet vermeld, zoals het Hof ook erkent. Dat maakt kennelijk niet uit en inderdaad raakt de duur van vakantie de kern van de zaak ook niet. Tegelijk kun je zeggen dat ook de invulling van de duur een zekere concretisering van het recht op vakantie is. Dat is niet alleen een theoretische discussie, maar van groot belang voor twee momenteel bij het Hof aanhangige zaken, te weten TSN en AKT. De verwijzende rechters in die zaken hebben onder meer gevraagd of artikel 31 lid 2 Handvest ook ziet op vakantie die de vereiste minimumduur van vier weken overschrijdt. Die vraag vertoont gelijkenissen met de zaak Neidel, die een vergelijkbare vraag beantwoordde over de richtlijn. ${ }^{129}$ In dat arrest oordeelde het Hof dat de richtlijn zich inderdaad beperkt tot de wettelijke vakantieduur van vier weken. Als dat ook voor het Handvest het geval blijkt, maakt het ontbreken van de duur in artikel 31 lid 2 Handvest inderdaad niet uit. Beantwoordt het Hof die vragen echter ontkennend, dan is moeilijk vol te houden dat de duur van vakantie niet uitmaakt; artikel 31 lid 2 Handvest moet dan immers nader worden ingevuld en is dan niet self-executing. In zijn conclusie heeft A-G Bot ervoor gepleit artikel 31 lid 2 Handvest enkel te laten zien op de vier weken wettelijke vakantie. ${ }^{130} \mathrm{Nu}$ is het in het concrete geval wellicht te billijken dat de duur van vakantie als vanzelfsprekend op vier weken moet worden gesteld, maar wellicht opent deze redenering wel de deur voor verdere, minder voor de hand liggende 'reparaties' van het Handvest. ${ }^{131}$

Een gerelateerd probleem zit in de overweging dat het recht op vakantie niet nader hoeft te worden geconcretiseerd door nadere bepalingen (van hetzij EUrecht, hetzij nationaal recht), omdat die louter de voorwaarden voor uitoefening van het recht aangeven. Die redenering lijkt logisch, zeker omdat het Hof deze lijn in de rechtspraak over Richtlijn 2003/88 steevast hanteert. Het Hof is immers streng waar het gaat om het stellen van voorwaarden aan het ontstaan van het recht op vakantie, zo blijkt bijvoorbeeld uit de arresten BECTU en Dominguez. Zo kan de wetgever het recht op vakantie niet pas toekennen als de werknemer een minimumperiode heeft gewerkt. Uitvoeringsmodaliteiten zijn echter wel toege-

127 Arrest Bauer, nr. 85.

128 Verburg 2015, p. 192, suggereerde dit reeds.

129 Arrest Neidel, reeds aangehaald.

130 Conclusie A-G Bot bij gevoegde zaken TSN (C-609/17) en AKT (C-610/17), ECLI:EU:C:2019:459, nrs. 106-113.

131 In de woorden van A-G Bobek in zijn conclusie bij Cresco Investigation (ECLI:EU:C:2018:614): 'Grondrechtenverklaringen zijn doorgaans vrij abstract en dus vaag. Dit geldt ook voor het Handvest. In de regel zijn er uitvoeringsregelingen nodig om de inhoud van dergelijke verklaringen in rechte te kunnen afdwingen. Als de desbetreffende bepalingen op zichzelf horizontale rechtstreeks werking hadden met betrekking tot de rechten en verplichtingen van particulieren, zou dit leiden tot extreme vormen van rechterlijke creativiteit.' 
staan, mits zij het recht op vakantie niet het nuttig effect ontnemen. Het Hof overweegt dit in Max-Planck nog expliciet, zie ook paragraaf 6.2.

Dat roept echter wel de vraag op waarom die uitvoeringsvoorwaarden in AMS dan een onoverkomelijke horde waren. Een mogelijke reden hiervoor zou kunnen zijn dat artikel 27 Handvest het recht op medezeggenschap toekent 'in de gevallen en onder de voorwaarden waarin het recht van de Unie en de nationale wetgevingen en praktijken voorzien' en je die nationale wetgeving dus eerst moet kennen voordat aanspraak op een recht ontstaat. Dat overtuigt echter niet volledig.

Allereerst is het de vraag of een recht uit het Handvest geen horizontale rechtstreekse werking zou moeten krijgen enkel omdat het naar andere wetgeving verwijst. ${ }^{132}$ Dit geldt temeer nu het verschil tussen artikel 27 en artikel 31 lid 2 Handvest niet zo groot is als het Hof doet voorkomen. Artikel 31 lid 2 Handvest is immers - zo hebben we gezien - min of meer volledig gevormd door artikel 7 Richtlijn 2003/88 en dat laatste artikel kent werknemers vakantie toe 'overeenkomstig de in de nationale wetten en/of gebruiken geldende voorwaarden voor het recht op en de toekenning van een dergelijke vakantie'. Daar lijkt enige interpretatieruimte in te zitten. Artikel 27 Handvest is onder meer gebaseerd op Richtlijn 2002/14. ${ }^{133}$ De in AMS aan de orde zijnde artikelen uit die richtlijn laten juist weinig ruimte voor interpretatie. Artikel 2 van die richtlijn definieert een werknemer namelijk als 'een persoon die in de betrokken lidstaat op grond van het nationale arbeidsrecht en volgens de nationale praktijk bescherming geniet als werknemer', terwijl artikel 3 sub a de richtlijn van toepassing verklaart op ondernemingen die in een lidstaat minimaal vijftig werknemers in dienst hebben. Zo verschillen artikel 27 Handvest en Richtlijn 2002/14 enerzijds en artikel 31 lid 2 Handvest en Richtlijn 2003/88 anderzijds niet heel erg in de wijze waarop de verhouding tussen 'recht' en 'voorwaarden' in de praktijk is uitgewerkt. In beide gevallen volgt uit een gezamenlijke lezing van de artikelen vrij duidelijk wat de strekking ervan is. Ook dat doet wat mij betreft afbreuk aan het argument van het Hof om in AMS geen en in Bauer en Max-Planck wél rechtstreekse werking toe te staan.

Het is daarbij moeilijk te verklaren dat artikel 27 Handvest blijkens AMS niet in samenhang met Richtlijn 2002/14 mag worden gelezen omdat het Handvestartikel op zichzelf moet volstaan, ${ }^{134}$ terwijl artikel 31 lid 2 Handvest misschien dan qua tekst op zichzelf kan volstaan, maar in feite volledig wordt ingevuld door Richtlijn 2003/88 (zie paragraaf 6.3). En dan eigenlijk niet eens door de tekst van de richtlijn, maar door de jurisprudentie erover. Dogmatisch gezien valt dit laatste nog wel te verdedigen. De bescherming van het Handvest in Max-Planck komt immers tot stand doordat het Hof het verval van vakantieaanspraken, zonder aan de inspanningsplicht te hebben voldaan, beschouwt als illegitieme uitvoeringsmodaliteit die inbreuk maakt op het algemene recht op vakantie. Op diezelfde wijze valt het recht van nabestaanden op niet-genoten vakantie te zien als een recht dat voortvloeit uit artikel 7 lid 2 van de richtlijn en daarmee het Handvest. Dat neemt

132 Zie in gelijke zin Dorssemont 2014, p. 717.

133 Toelichting bij het Handvest 2007, p. 10 (artikel 27).

134 Arrest AMS, nr. 49. 
niet weg dat het verschil in behandeling opmerkelijk is. De toegangspoort is kennelijk erg klein, maar eenmaal binnen lijken de mogelijkheden grenzeloos. ${ }^{135}$ Het Hof is ook op een ander punt niet consequent. Zo weten we al sinds het arrest BECTU dat de zinsnede 'overeenkomstig de in de nationale wetten en/of gebruiken geldende voorwaarden voor het recht op en de toekenning van een dergelijke vakantie' uit artikel 7 Richtlijn 2003/88 beperkt moet worden opgevat: het ontstaan van het recht op vakantie zelf mag niet worden beperkt. Dat valt uit een letterlijke lezing van de tekst van de richtlijn echter niet op te maken. En juist een letterlijke lezing van de Handvest-bepalingen lijkt voor het Hof weer zo belangrijk waar het gaat om de vraag of zij horizontaal en rechtstreeks kunnen doorwerken. Gezien voornoemde problemen meen ik dat horizontale directe werking niet zo eenvoudig is als het lijkt, zeker niet als we ervan moeten uitgaan dat het Hof in AMS en Bauer hetzelfde criterium heeft aangelegd. Mak meent echter dat het Hof met Bauer is teruggekomen van AMS, dat volgens haar nog uitging van horizontale directe werking van het Handvest als uitzondering. Dit leidt zij af uit het feit dat de arresten AMS en Bauer op het punt van rechtstreekse werking anders zijn opgebouwd. ${ }^{136}$ Ik durf niet volledig uit te sluiten dat Mak hierin gelijk heeft, maar ik meen dat dit niet het geval is. Mak lijkt haar indruk vooral te baseren op het feit dat Bauer anders is opgebouwd dan AMS. Die indruk deel ik niet. Mij lijkt de methode die het Hof hanteert in Bauer gelijk aan die in AMS. Het ligt daarom in de rede dat het Hof een koerswijziging wat explicieter zou hebben benoemd.

Als niettemin toch sprake is van een koerswijziging, zou dit bijvoorbeeld het probleem van de verhouding tussen een Handvest-bepaling en de invulling daarvan aan de hand van een richtlijn wegnemen. Tegelijkertijd is dan wel de vraag wat nu de ondergrens is voor het aannemen van horizontale directe werking.

\subsection{Wat heeft dan precies rechtstreekse werking?}

Horizontale rechtstreekse werking van het Handvest houdt in dat het Handvest direct treedt in de rechtsverhouding tussen particulieren. Dat zien we in deze zaken ook gebeuren: het Handvest zet Duitse bepalingen opzij, althans: de Duitse rechter moet de met het Handvest strijdige bepalingen buiten toepassing laten. In de concrete gevallen betekent dit dat een recht ontstaat op de vergoeding voor niet-genoten vakantie (Bauer), dan wel dat de vakantieaanspraken niet zijn vervallen en dus moeten worden uitbetaald (Max-Planck).

Het is belangrijk te bepalen waar het recht uit het Handvest begint en (vooral) waar het eindigt. Zodra de Handvest-bescherming niet meer van toepassing is, geldt immers enkel nog de bescherming die de richtlijn biedt. In dat geval kunnen particulieren zich niet meer rechtstreeks jegens elkaar aan de (richtlijn)bepaling

135 In reactie op een eerdere versie van dit artikel suggereerde B.P. ter Haar dat het verschil tussen AMS enerzijds en Bauer en Willmeroth anderzijds het gevolg kan zijn van het feit dat gelijke behandeling en arbeidsomstandigheden (arbeidstijden en vakantie daaronder begrepen) in 'Europa' politiek beter te verkopen zijn. Bij informatie en consultatie ligt dit anders, nu dat een politiek veel gevoeliger onderwerp is. Ik sluit niet uit dat dergelijke overwegingen inderdaad een rol spelen. Tegelijk lijkt het mij geen argument dat voor het Hof zou mogen meewegen.

136 Arrest Bauer, noot C. Mak in EHRC 2019/19. 
beroepen. Op dat moment gaat van het Europese recht enkel nog indirecte werking uit.

In paragraaf 7 besprak ik reeds de invulling van artikel 31 lid 2 Handvest door het Hof. Die lijkt letterlijk door de richtlijn te zijn ingegeven. Als die veronderstelling juist is, heeft heel artikel 7 van de richtlijn via artikel 31 lid 2 Handvest horizontale directe werking. Dat omvat dan het recht zelf, de uitvoeringsmodaliteiten en ook artikel 7 lid 2, dat het afkoopverbod (en de afkoopplicht bij einde van het dienstverband) betreft. Bauer betrof immers uiteindelijk artikel 7 lid 2 van de richtlijn, en de vervaltermijn in Max-Planck betrof een (verboden) uitvoeringsmodaliteit.

Trekken we deze lijn door, dan zijn ook andere uitvoeringsmodaliteiten vermoedelijk aan horizontale directe werking onderhevig. Dit kan dus gelden voor vervaltermijnen, maar ook voor andere bepalingen, bijvoorbeeld over de hoogte van vakantieloon of bepalingen over cumulatie van vakantie en ziekte. Stuk voor stuk kunnen zij direct worden getoetst aan het Handvest. Wat niet zelf het recht op vakantie schept, is immers al snel een uitvoeringsmodaliteit. Totdat het Hof ergens een grens trekt, lijkt het er dan ook op dat de gehele vakantiewetgeving aan horizontale directe werking van het Handvest onderworpen is en dus ook opzij kan worden gezet.

\subsection{Kunnen particulieren rechten aan het Handvest ontlenen?}

Een andere discussie betrof de vraag of particulieren sowieso wel rechten aan het Handvest konden ontlenen. Deze discussie was ingegeven door de formulering van artikel 51 lid 1 Handvest. Blijkens deze bepaling is het Handvest gericht tot de EU (instellingen, organen en instanties) en lidstaten, wanneer zij EU-recht uitvoeren. ${ }^{137}$ Particulieren komen in deze bepaling niet voor; het was dus de vraag of het Handvest ook voor hen gold. In de literatuur waren er twee stromingen. De eerste stroming betoogde dat het Handvest niet direct doorwerkt tussen particulieren, nu het Handvest zich niet tot hen richt. ${ }^{138}$ Anderen waren van oordeel dat het Handvest ook wel degelijk tussen particulieren werkte, met name omdat de bepaling niets zou regelen omtrent burgers. ${ }^{139}$

In twee verschillende zaken hadden twee verschillende A-G's deze vraag verschillend beantwoord. Zo concludeerde A-G Trstenjak (in haar conclusie voor Dominguez) dat artikel 51 lid 1 Handvest de kring van geadresseerden beperkte, waardoor het Handvest niet tussen particulieren kon gelden. ${ }^{140}$ A-G Cruz Villalón pleitte in zijn conclusie voor AMS echter voor horizontale directe werking van het Handvest, nu grondrechten toch al horizontaal werden toegepast en het Hand-

137 Zie uitvoerig - inclusief alle nuances - Barkhuysen e.a. 2011, NTBR 2011/68, par. 3.3

138 Zie bijv. P.C. Vas Nunes, Kücükdeveci: een wake-up call, TAP 2010/4, p. 150-151; T. van Peijpe, Toepassing van EU-grondrechten in nationaal arbeidsrecht, TRA 2012/76, par. 2.4; M. de Mol, De horizontale directe werking van de grondrechten van de Europese Unie, SEW 2016/11, p. 463. Laatstgenoemde besteedt in haar proefschrift overigens uitvoerig aandacht aan deze materie. Zie M. de Mol, De directe werking van de grondrechten van de Europese Unie, Oisterwijk: Wolf Legal Publishers 2014.

139 Bijv. Asser/Hartkamp 3-I 2018/231f. Zie voor een uitvoerig overzicht Ward 2014, p. 1413-1454.

140 Conclusie A-G Trstenjak in Dominguez, ECLI:EU:C:2011:559, nrs. 80-83. 
vest toch bij uitstek de grondrechtencatalogus van de EU is. ${ }^{141}$ Dat particulieren niet in artikel 51 lid 1 Handvest worden genoemd, betekende volgens hem niet dat zij zich er niet op zouden kunnen beroepen. ${ }^{142}$ Het zou vreemd zijn dat andere grondrechten uit het Handvest een minder goede behandeling zou toekomen dan de fundamentele vrijheden van de Unie en het gelijkheidsbeginsel (Mangold en Kücukdeveci) ${ }^{143}$ In beide arresten had het Hof zich echter niet over de materie hoeven uitlaten; Dominguez kon zich - indien richtlijnconforme interpretatie in haar geval onmogelijk zou blijken - ten opzichte van haar (overheids)werkgever rechtstreeks op de richtlijn beroepen, terwijl artikel 27 Handvest in AMS niet geschikt bleek voor horizontale directe werking.

In Bauer volgt alsnog uitsluitsel. Het blijkt eigenlijk een non-issue. A-G Bot had overwogen dat artikel 51 Handvest horizontale werking niet uitsluit en dat het Hof aan verschillende bepalingen, die aanvankelijk ook enkel aan lidstaten waren gericht, horizontale werking heeft toegekend. ${ }^{144}$ Het Hof maakt er niet veel meer woorden aan vuil. Het verwijst naar de conclusie van de A-G en voegt hieraan toe dat het in de zaak Egenberger ook rechtstreekse werking tussen particulieren heeft aanvaard. ${ }^{145}$

\subsection{Rechtsgevolgen}

$\mathrm{Nu}$ aan alle vereisten voor rechtstreekse werking is voldaan, concludeert het Hof dat het gevolg is dat de nationale rechter de rechtsbescherming die volgt uit artikel 31 lid 2 Handvest moet verzekeren. De volle werking ervan moet worden gewaarborgd, zo nodig door de nationale regeling buiten toepassing te laten. Met andere woorden: de Kücükdeveci-techniek vindt dus ook bij het Handvest toepassing. Anders gezegd wordt Kücükdeveci (en zo ook Mangold en Egenberger) nu doorgetrokken voorbij het beginsel van non-discriminatie. ${ }^{146}$ Daarmee geeft het Hof uiting aan de verwachting (of de wens?) die de Europese Commissie in haar interpretatieve mededeling over Richtlijn 2003/88 uitsprak. ${ }^{147}$

De rechtsgevolgen gaan echter verder dan het buiten toepassing laten van nationale wetgeving alleen. De arresten Bauer en Max-Planck introduceren ook een ander type verplichting. De non-discriminatiezaken legden op werkgevers een negatieve verplichting; zij konden zich niet beroepen op een wetsbepaling die discriminatoir bleek. Bauer en Max-Planck leggen juist een positieve verplichting op de werkgever, namelijk een verplichting tot betaling van een vergoeding en een inspanningsplicht die nodig is voordat verval van niet-genoten vakantie een optie kan zijn. Het Hof lijkt hier ook op te wijzen met overweging nr. 90 in Bauer dat het recht van de werknemer een overeenkomstige verplichting voor de werkgever inhoudt. Werkgevers moeten dus iets doen.

141 Conclusie A-G Cruz Villalón in AMS, nrs. 34-35.

142 Conclusie A-G Cruz Villalón in AMS, nrs. 28-41.

143 Conclusie A-G Cruz Villalón in AMS, nr. 34.

144 Conclusie A-G in Bauer, nr. 78.

145 Arrest Bauer, nrs. 87-89, deels onder verwijzing naar arrest Egenberger, nrs. 76-77.

146 Zie in gelijke zin Eleveld 2019, p. 92-93.

147 PbEU 2017/C 165/01, p. 34 (slot van par. VII.A.4). 
Het Hof heeft inmiddels al laten merken dat die positieve verplichting ver kan gaan, zo blijkt uit het arrest Cresco Investigation. ${ }^{148}$ In die zaak kregen Oostenrijkse werknemers die lid waren van bepaalde evangelische kerken een vrije dag op Goede Vrijdag, of een salaristoeslag als zij toch moesten werken. Niet-leden kregen die toeslag niet. Het Hof achtte dit discriminatoir. Het voegde hieraan echter toe dat werkgevers de toeslag moesten voldoen aan alle werknemers die op Goede Vrijdag werkten, mits zij vooraf toestemming vroegen op die dag niet te hoeven werken maar dit toch moesten, zolang de Oostenrijkse wetgever de wet niet heeft gewijzigd. ${ }^{149}$ Het Handvest lijkt in die zaak dus een zelfstandige basis voor een verdergaande (betalings)plicht.

\section{Gevolgen voor de praktijk}

\subsection{Grondrechtenbescherming en rechts(on)zekerheid}

Enerzijds is het toe te juichen dat het Handvest horizontale directe doorwerking toekomt. Het Handvest is immers de Europese grondrechtencatalogus, die bovendien verdragsstatus heeft. Er is geen goed argument het Handvest buiten beschouwing te laten. Burgers krijgen in toenemende mate rechtsbescherming. Tegelijk zijn er grenzen. Veel van de grondrechten zijn uitgewerkt in richtlijnen. Het Hof sluit horizontale directe werking van die richtlijnen uit. Als dit nu met een beroep op het Handvest kan worden omzeild, wekt dat slechts rechtsonzekerheid in de hand. ${ }^{150}$ Daar kan men tegenin brengen dat een richtlijn een invulling kan vormen van het Handvest, zoals in zowel Max-Planck als Bauer het geval is, maar dan is de vraag waarom men in die gevallen niet gewoon rechtstreeks de richtlijn zou moeten kunnen inroepen. A-G Bobek verwoordt het in zijn conclusie bij Cresco Investigation helder:

'Het lijkt alsof er steeds meer vraagtekens kunnen worden geplaatst bij de volharding waarmee formeel wordt ontkend dat richtlijnen horizontale rechtstreekse werking hebben, maar tegelijkertijd hemel en aarde wordt bewogen om te voorkomen dat die beperking überhaupt praktische gevolgen heeft, door bijvoorbeeld de inhoud van een richtlijn op te nemen in een bepaling van het Handvest. ${ }^{151}$

Een ander probleem is vooral getoond door Max-Planck. De inspanningsplicht voor werkgevers die in dit arrest is geïntroduceerd, is niet voorzien en dus nieuw. Tegelijk heeft de inspanningsverplichting meteen horizontale directe werking. Dat is te billijken als de uitkomst van een zaak goed voorspelbaar is. Dat was in Max-Planck niet het geval. Het was best mogelijk geweest dat het Hof zou hebben geoordeeld dat opgebouwde vakantie in hetzelfde jaar vervalt, tenzij de

148 HvJ EU 22 januari 2019, C-193/17, ECLI:EU:C:2019:43 (Cresco Investigation).

149 Zie hierover uitgebreid De Mol 2019, de annotatie van J.H. Gerards en C. Mak bij Cresco Investigation in EHRC 2019/66 en Eleveld 2019, p. 93-94.

150 Laagland (2016) bespreekt een soortgelijk rechtszekerheidsargument uitgebreid.

151 Conclusie A-G Bobek in Cresco Investigation, nr. 145. 
werknemer redelijkerwijs niet in staat is geweest vakantie op te nemen - dit echter zonder inspanningsplicht van de werkgever. Nu maakt het Hof een keuze die werkgevers meteen voor verplichtingen stelt en vereist dat werkgevers zich van Europese jurisprudentie op de hoogte stellen, dit naast kennis van de nationale wetten. De zaak Cresco Investigation maakt duidelijk dat dit voor werkgevers zelfs een extra betalingsplicht kan betekenen. Dat gaat ver.

\subsection{Andere Handvest-bepalingen}

Een belangrijke vraag is of de lijn uit Bauer naar andere Handvest-bepalingen doorgetrokken gaat worden en, toegespitst op dit tijdschrift, welke van die bepalingen arbeidsrechtelijk relevant zijn. Dat is speculeren, maar duidelijk is dat zich nieuwe vragen zullen gaan voordoen.

Zo ligt er een reële mogelijkheid voor de groep die in het EU-recht als werknemer of schijnzelfstandige wordt aangeduid, maar in Nederland niet de status van werknemer heeft. ${ }^{152}$ Deze groep zou rechtstreeks rechten kunnen ontlenen aan het Handvest. Dan gaat het niet alleen om het recht op vakantie met behoud van loon, maar ook om artikel 21 (non-discriminatie). Dat laatste kan bijvoorbeeld het geval zijn voor platformarbeiders. ${ }^{153}$ Voor zover zij niet onder de Wet allocatie arbeidskrachten door intermediairs vallen en daarmee artikel 3 niet zouden kunnen inroepen, ${ }^{154}$ zouden zij wellicht ook een beroep kunnen doen op artikel 29 (kosteloze arbeidsbemiddeling).

\subsection{Gevolgen voor de Nederlandse vakantiewetgeving}

Ook voor de Nederlandse vakantiewetgeving heeft het arrest Max-Planck gevolgen. Het gaat dan om de vervaltermijn uit artikel 7:640a BW en de verjaringstermijn uit artikel 7:642 BW. De vervaltermijn schrijft voor dat de wettelijke vakantieaanspraak vervalt zes maanden na het jaar waarin het recht op vakantie is ontstaan, tenzij de werknemer redelijkerwijs niet in staat is geweest de vakantie op te nemen. Dan geldt conform artikel 7:642 BW de verjaringstermijn van vijf jaar. ${ }^{155}$

Sinds Conley King weten we al dat in elk geval artikel 7:642 BW niet richtlijnconform is. Dit artikel voorziet immers niet in een 'uitlaatklep' die in voorkomende gevallen voorkomt dat het recht op vakantie vervalt of verjaart, zoals deze wel in artikel 7:640a BW is opgenomen. ${ }^{156}$ De mogelijkheid verjaring te stuiten lijkt althans onvoldoende. Ook dat volgt impliciet uit Max-Planck, nu stuiting zou

152 Zie over het werknemersbegrip uitgebreid F.G. Laagland, Voorbij de grenzen van het Nederlandse werknemersbegrip, Ondernemingsrecht 2018/130.

153 Zie bijv. M. Kullmann, Platformwerk, besluitvorming door algoritmen en bewijs van algoritmische discriminatie, Ondernemingsrecht 2019/8; S. Burri \& S. Heeger-Hertter, Discriminatie in de platformeconomie juridisch bestrijden: geen eenvoudige zaak, AA 2018/12, p. 1000-1008.

154 Zie hierover E. Verhulp, Platformwerkers verdienen meer!, ArbeidsRecht 2018/1; J.H. Bennaars, Is platformwerk een bedreiging of een kans voor het arbeidsrecht? Het antwoord is ja, ArbeidsRecht 2018/28.

155 Kamerstukken II 2009/10, 32465, 3, p. 8 en 11.

156 Zie bijv. mijn noot bij HvJ EU 29 november 2017, C-214/16 (Conley King) in JIN 2018/43 en W.L. Roozendaal, Verjaring van vakantieaanspraken in geval van schijnzelfstandigheid, AR Updates 2018-0055. 
betekenen dat de verantwoordelijkheid voor het opnemen van vakantie weer naar de werknemer zou worden verschoven.

Artikel 7:640a BW valt nog richtlijnconform te interpreteren, hoewel het geen gek idee zou zijn de inspanningsplicht van de werkgever in dit artikel neer te leggen. Artikel 7:642 BW moet sowieso worden aangepast, ondanks de ontstane mogelijkheid het artikel met een beroep op het Handvest buiten toepassing te laten. Artikel 288 VWEU verplicht het de lidstaten immers richtlijnen te implementeren.

Theoretisch gezien blijft ook de mogelijkheid van staatsaansprakelijkheid nog bestaan. Het lijkt moeilijk voorstelbaar dat de staat zich met een beroep op de doorwerking van het Handvest zou kunnen disculperen. Overigens zal een werknemer doorgaans toch eerder de route van het Handvest willen nemen dan voor staatsaansprakelijkheid te kiezen. Eerder kan men zelfs misschien nog denken aan werkgevers die de staat aansprakelijk stellen voor onrechtmatige wetgeving, hoewel ik niet direct inzie welke schade zij vergoed zouden kunnen zien. Zij lijden immers niet zozeer schade door onrechtmatige wetgeving; was de wet in overeenstemming geweest met het Unierecht, dan zouden zij immers dezelfde verplichtingen hebben gehad.

De tweede ontwikkeling is uiteraard - zoals in paragraaf 7.5 beschreven - dat het Handvest direct kan doorwerken in de vakantiewetgeving. Met het recht op vakantie strijdige bepalingen zullen buiten toepassing moeten worden gelaten. Afgezien van de genoemde bepalingen lijkt dat op dit moment wellicht nog een ver-van-mijn-bedshow, maar het zou niet voor de eerste keer zijn dat het Hof van Justitie de wetgever verrast met zijn interpretatie van de Arbeidstijdenrichtlijn. Zo zou het arrest Schultz-Hoff een grote financiële impact op werkgevers hebben gehad als het recht op vakantie op dat moment (in 2009) al horizontale directe werking was toegekomen.

Een mogelijke derde ontwikkeling is dat het afdwingen van vakantie op grond van artikel 7:611 BW nieuw leven wordt ingeblazen. In aanloop naar de wijziging van de vakantiewetgeving in 2000 kwam aan de orde of de werkgever een werknemer kan dwingen vakantie op te nemen. De wetgever stelde dat dit onder omstandigheden mogelijk zou zijn op grond van het goed werkgeverschap. ${ }^{157}$ In een enkele zaak is die grondslag ook succesvol gebruikt om vakantie af te dwingen, maar dit was wel uitzonderlijk. ${ }^{158}$ Het is denkbaar dat werkgevers dit als gevolg van de in Max-Planck geïntroduceerde inspanningsplicht zullen gaan proberen. Op die manier kan een werkgever wellicht voorkomen dat hij in een discussie geraakt of hij wel op correcte wijze aan de informatieverplichting heeft voldaan. Zo kan een geschil over het al dan niet vervallen zijn van niet-opgenomen vakantiedagen wellicht worden voorkomen.

157 Kamerstukken I 1999/2000, 26079, 176, p. 11.

158 J.R. Vos, Cash of costa: de aanpak van vakantiestuwmeren nader bezien, Den Haag: Boom Juridische uitgevers 2012, p. 35-36. 


\section{Conclusie}

De '6 november-arresten' mogen met recht als landmark cases worden gezien. Zij hebben het Handvest toegankelijker gemaakt voor de EU-burger en zetten ook het recht op vakantie (wederom) steviger neer.

De in het arrest Max-Planck geïntroduceerde inspanningsverplichting is een actieve verplichting voor de werkgever die we nog niet kenden. Waar de werkgeversverplichting in de afgelopen twee decennia weliswaar steeds verder werd opgerekt, maar altijd een faciliterend karakter had, moet deze nu actief waarborgen dat een werknemer zijn vakantie opneemt.

Stap voor stap nemen de verplichtingen aan werkgeverszijde toe. Groot probleem hierbij is mijns inziens dat die verplichtingen (al lang) niet goed meer uit de tekst van Richtlijn 2003/88 zijn af te leiden. Dat komt de rechtszekerheid niet ten goede. Gezien de horizontale directe werking via artikel 31 lid 2 Handvest wordt dit alleen maar problematischer, zeker omdat werkgevers niet meer op hun nationale wetgeving kunnen afgaan. Er zullen weinig sociale grondrechten zijn die zo slecht gereguleerd zijn. Dat is volgens mij ook de reden dat relatief zoveel jurisprudentie de vakantiewetgeving betreft. Nadere regelgeving van de EU zou dan ook welkom zijn. Inspiratie hiervoor biedt wellicht ILO-Verdrag nr. 132 (over vakantie met behoud van loon), dat maar liefst 24 artikelen kent, waarvan 16 inhoudelijke.

Het Handvest krijgt van het Hof een prominente plaats in de rechtsbescherming, en de horizontale directe doorwerking van Handvest-bepalingen is nu ook voorbij het beginsel van non-discriminatie doorgetrokken. Sociale grondrechten lijken nu ook bescherming te genieten. Het is interessant te zien hoe het leerstuk horizontale directe werking zich in het Europees recht verder zal ontwikkelen. Voor de praktijkjurist is de belangrijkste vraag niet zozeer of maar meer welke Handvestbepalingen eveneens voor horizontale directe werking in aanmerking komen. ${ }^{159}$ In elk geval staan ons interessante ontwikkelingen te wachten.

159 Zie voor een verder overzicht van openstaande vragen De Mol 2019, par. 6. 